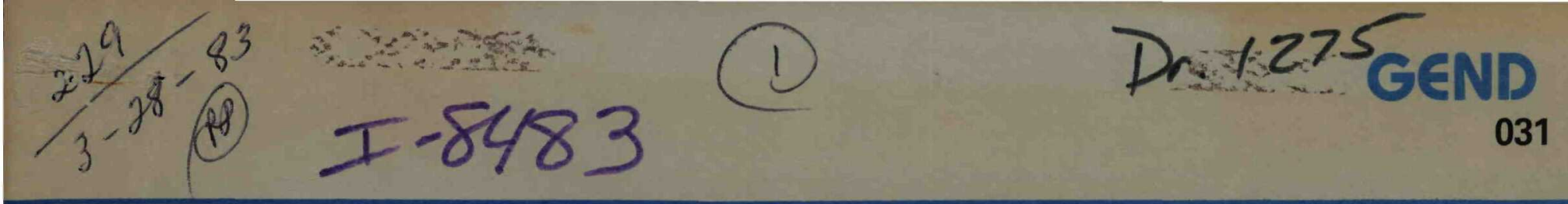

\title{
GEND
}

General Public Utilities - Electric Power Researeh Institute • U.S. Nuclear Regulatory Commission • U.S. Department of Energy

\section{Submerged Demineralizer System Processing of TMI-2 Accident Waste Water}

Herbert F. Sanchez

Geoffrey J. Quinn

February 1983

Prepared for the 
Printed in the United States of America

Available from

National Technical Information Service

U.S. Department of Commerce

5285 Port Royal Road

Springfield, VA 22161

NTIS Price Codes: Printed Copy A04

Microfiche A01

\section{DISCLAIMER}

This book was prepared as an account of work sponsored by an agency of the United States Government. Neither the United States Government nor any agency thereof, nor any of their employees, makes any warranty, express or implied, or assumes any legal liability or responsibility for the accuracy, completeness, or usefulness of any information, apparatus, product or process disclosed, or represents that its use would not infringe privately owned rights. References herein to any specific commercial product, process, or service by trade name, trademark, manufacturer, or otherwise, does not necessarily constitute or imply its endorsement, recommendation, or favoring by the United States Government or any agency thereof. The views and opinions of authors expressed herein do not necessarily state or reflect those of the United States Government or any agency thereof. 


\section{DISCLAIMER}

Portions of this document may be illegible in electronic image products. Images are produced from the best available original document. 
GEND- -031

DE8 3009223

GEND 031

Distribution Category: UC-78

TMI Supplement

\title{
DISCLAIMER
}

This report was prepared as an account of work sponsored by an agency of the United States Government. Neither the United States Government nor any agency thereof, nor any of their employees, makes any warranty, express or implied, or assumes any legal liability or responsibility for the accuracy, completeness, or usefulness of any information, apparatus, product, or process disclosed, or represents that its use would not infringe privately owned rights. Reference herein to any specific commercial product, process, or service by trade name, trademark, manufacturer, or otherwise does not necessarily constitute or imply its endorsement, recommendation, or favoring by the United States Government or any agency thereof. The views and opinions of authors expressed herein do not necessarily state or reflect those of the United States Government or any agency thereof.

\section{SUBMERGED DEMINERALIZER SYSTEM PROCESSING OF TIIML2 ACCIDENT WASTE WATER}

\author{
Herbert F. Sanchez \\ Geoffrey J. Quinn
}

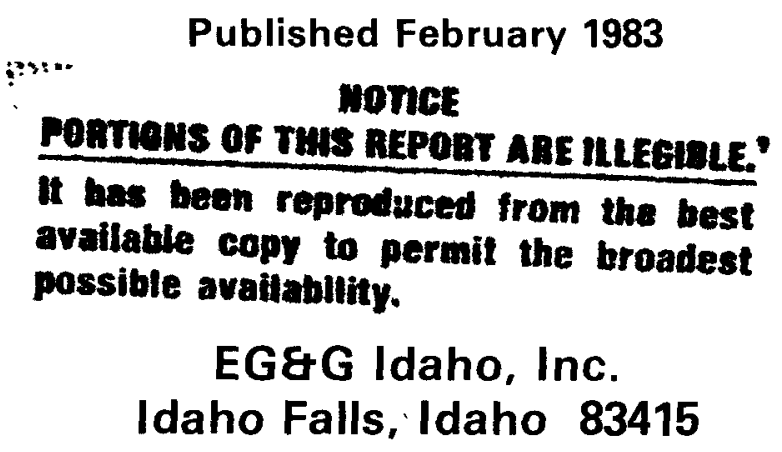

Prepared for the

U.S. Department of Energy

Three Mile Island Operations Office

Under DOE Contract No. DE-AC07-76ID01570 


\section{ABSTRACT}

Accident-generated radioactive waste at Three Mile Island Unit 2 includes a variety of high and low specific-activity waste. The high-specificactivity waste, particularly over one million gallons of contaminated water, required special processing and secondary waste handling. General Public Utilities and its contractors, with technical assistance from the U.S. Department of Energy, developed a zeolite-based ion-exchange system called the Submerged Demineralizer System to reduce contamination levels in the water to below allowable limits. Testing and modifications resulted in an operating system that had successfully processed waste water from the Reactor Coolant Bleed Tanks, the Reactor Building Basement, and the Reactor Coolant System as of August 1982. System design objectives were met and decontamination criteria established in 10 CFR 20 were attained.

Additional wastes that could not be handled routinely were generated by another water-processing system, called EPICOR II. EPICOR II wastes are discussed in Appendix A.

Low-specific-activity (LSA) wastes sucht as thas and resin-bed waste canisters are also included in waste handling at Three Mile Island Unit 2. LSA wastes are routinely handled and shipped according to existing industry practice. Plant records are summarized in Appendix $B$ to provide approximate yearly volumes and curie loadings of low-specific-activity wastes being shipped off the Island to a commercial burial site. 


\section{ACKNOWLEDGMENTS}

The authors gratefully acknowledge the following individuals who provided careful review of technical data and many helpful suggestions on overall organization: S. J. Eichfeld, J. J. Galanto, M. W. Herlihy, C. G. Hitz, T. Lookabill, and T. E. Rekart of GPUNC; and J. H. Flaherty and R. E. Ogle of EG\&G Idaho, Inc. They especially wish to thank B. A. Ettinger of EG\&G Idaho, Inc. for providing thorough technical editing and for organizing materials for this report. 


\section{CONTENTS}

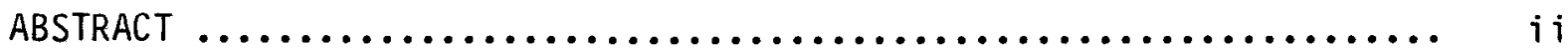

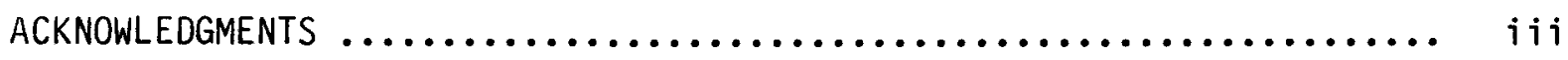

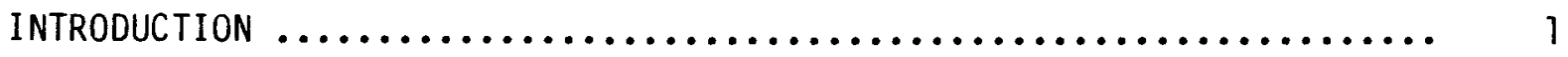

HISTORY OF SUBMERGED DEMINERALIZER SYSTEM DEVELOPMENT $\ldots \ldots \ldots \ldots \ldots \ldots .$.

Conceptual Design $\ldots \ldots \ldots \ldots \ldots \ldots \ldots \ldots \ldots \ldots \ldots \ldots \ldots \ldots \ldots \ldots$

Selection of Ion Exchange Media ....................... 4

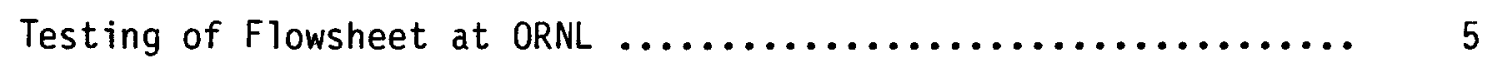

Increased Cesium Loading Studies $\ldots \ldots \ldots \ldots \ldots \ldots \ldots \ldots \ldots \ldots$

SYSTEM DESCRIPTION $\ldots \ldots \ldots \ldots \ldots \ldots \ldots \ldots \ldots \ldots \ldots \ldots \ldots \ldots \ldots \ldots \ldots$

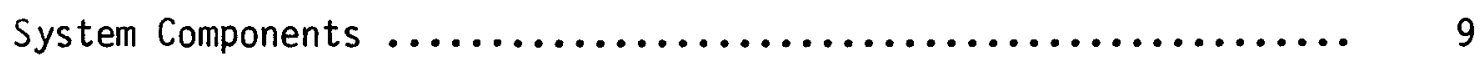

Feed Filtering System $\ldots \ldots \ldots \ldots \ldots \ldots \ldots \ldots \ldots \ldots \ldots \ldots \ldots \ldots$

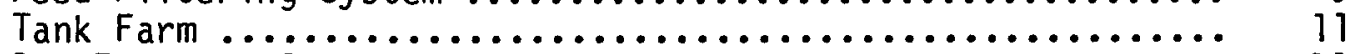

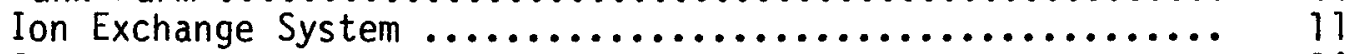

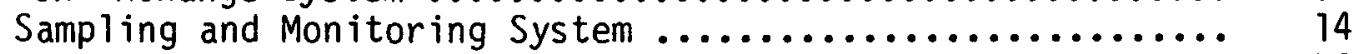

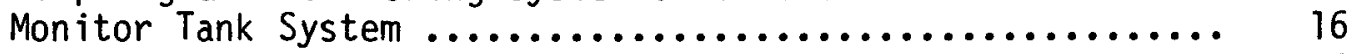

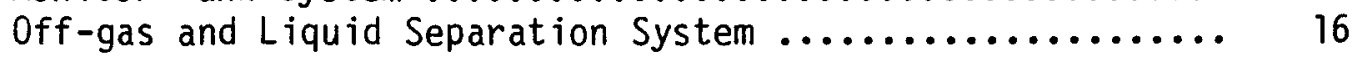

Arrangement of the System in the Spent Fuel Pool ............. 19

Preoperational Tests $\ldots \ldots \ldots \ldots \ldots \ldots \ldots \ldots \ldots \ldots \ldots \ldots \ldots \ldots \ldots \ldots$

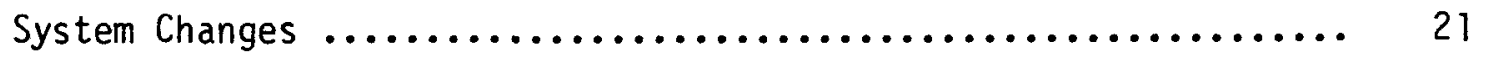

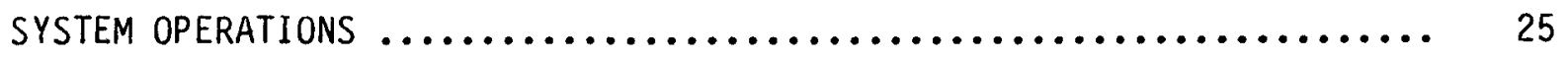

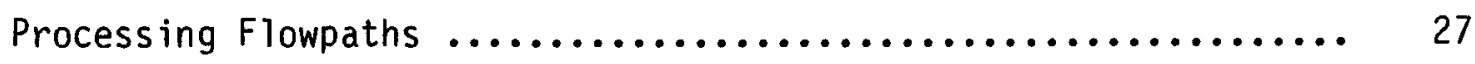

Reactor Coolant Bleed Tank Water Processing ............. 28

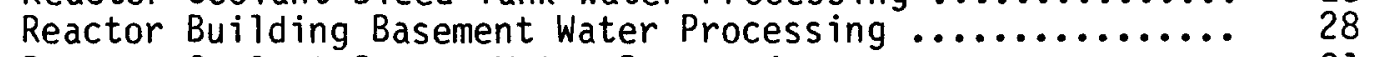

Reactor Coolant System Water Processing ............... 31 .

Radiation Protection ............................. 31

Radiation Protection Design Features ............... 33

Occupational Dose .............................. 34 
Processing History $\ldots \ldots \ldots \ldots \ldots \ldots \ldots \ldots \ldots \ldots \ldots \ldots \ldots \ldots \ldots \ldots \ldots \ldots \ldots \ldots, \quad 35$

Contamination Levels Before Processing .............. 35

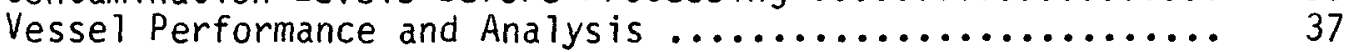

Sand and Cellulose Filter Analysis ................. 42

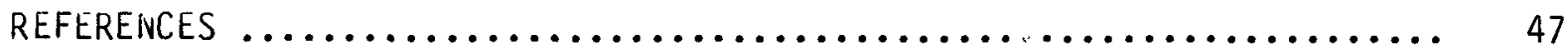

APPENDIX A--TMI-2 EPICOR II WASTE MANAGEMENT $\ldots \ldots \ldots \ldots \ldots \ldots \ldots . . . \ldots \ldots$

APPENDIX B--LOW SPECIFIC ACTIVITY WASTE $\ldots \ldots \ldots \ldots \ldots \ldots \ldots \ldots \ldots . \ldots \ldots$

APPENDIX C --10 CFR 20 CONCENTRATION LIMITS IN WATER ABOVE

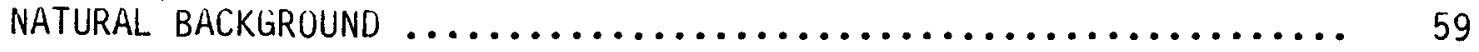

APPENDIX D--SDS VESSEL NOMENCLATURE $\ldots \ldots \ldots \ldots \ldots \ldots \ldots \ldots \ldots \ldots \ldots \ldots \ldots \ldots \ldots$

FIGURES

1. Original SOS flowsheet showing flowrates $\ldots \ldots \ldots \ldots \ldots \ldots \ldots \ldots . \ldots \ldots$

2. Cutaway view of cellulose and sand filter vessels ............ 10

3. Cutaway view of a SDS ion exchange vessel $\ldots \ldots \ldots \ldots \ldots \ldots \ldots . . . . . .12$

4. Sampling locations for monitoring SDS operation and 15

5. Flowpath through the monitoring tank system $\ldots \ldots \ldots \ldots \ldots \ldots \ldots . . \ldots \ldots$

6. Off-gas and liquid separation system $\ldots \ldots \ldots \ldots \ldots \ldots \ldots \ldots \ldots, 18$

7. Arrangement of SDS components in and around the

8. Functional areas testing sequence for SDS startup $\ldots \ldots \ldots \ldots \ldots 22$

9. Final flowsheet for water processing through the SDS $\ldots . \ldots \ldots .26$

10. Final flowsheet for RCBT water processing through the SDS ...... 29

11. Final flowsheet for Reactor Building Basement water

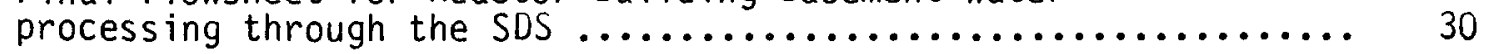

12. Final flowsheet for RCS water processing through the SDS ...... 32

\section{TABLES}

1. Ratios of Zeolite IE-96 to A-51 in SDS vessels .............. 13

2. Sample line locations and water streams monitored ............ 14 
3. Composition of contaminated water before SDS processing ...... 36

4. Solids in one-liter sample of Reactor Building Basement

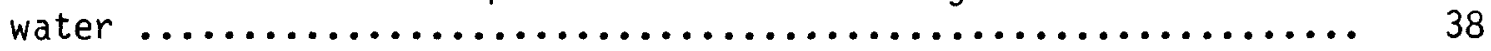

5. Volumetric flow through SDS vessels .................... 39

6. SDS batch processing history ....................... 40

7. Curie loadings on SDS zeolite liners after processing ........ 43

8. Volumetric flow through sand and cellulose filters .......... 44

9. Sand filter contents by grain particle size $\ldots \ldots \ldots \ldots \ldots \ldots \ldots . .45$

10. Cellulose and sand filter radioisotope analys is ............ 46 
SUBMERGED DEMINERALIZER SYSTEM PROCESSING

OF TMI - 2 ACC IDENT WASTE WATER

INTRODUCTION

Radioactive waste handling at Three Mile Island Unit 2 (TMI-2) has required adaptation and development of waste processing technology to handle the special wastes generated as a result of the March 28, 1979, acccident at the nuclear plant. This report discusses the accident radioactive waste handling system developed specifically for use at TMI-2.

The report discusses the Submerged Demineralizer System (SDS), developed to process accident-generated water predominantly contaminated with the radionuclides ${ }^{134,137} \mathrm{Cs}$ and ${ }^{90} \mathrm{Sr}$. Commercial nuclear waste processing companies developed the SDS for General Public Utilities, 'TMI-2's owner, with technical assistance from U.S. Department of Energy (DOE) national laboratories. The system uses inorganic zeolites to remove radionuclides from the contaminated water and concentrates them in a form suitable for safe shipment and disposition off-site.

Benefits from Submerged Demineralizer System operations at TMI include:

- The development and demonstration of a zeolite-based ion exchange system for removal of radionuclides. Zeolites permit higher specific activity waste loadings--without radiation-induced damage--than do the organic ion exchange resins now used by the commercial light water reactor industry.

a. General Public Utilities (GPU) is the parent company of General Public Utilities Nuclear Corporation (GPUNC), formed after SDS operations were well underway at TMI-2. GPUNC now supervises operation of GPU's nuclear facilities at TMI. All references to the operating utility will hereafter use the current name (GPUNC). 
- The development and demonstration of safe handling and disposition of highly loaded zeolite bed vessels. The handling, shipping, and disposition of zeolites loaded with large quantities of radionuclides required development of state-of-the-art technology.

- Decontamination of a large quantity of TMI-2 accident wastes to within decontamination criteria set forth in regulation 10 CFR 20. The decontamination of this water represented a significant milestone in the cleanup at the Unit 2 plant.

- The availability of highly loaded zeolite ion exchange media for research and development studies at DOE national laboratories.

Tn is report covers SDS history, development, and operations through August 1982, including processing of the first six batches of Reactor Coolant System water and Reactor Coolant Bleed Tank and Reactor Building Basement water.

Other GEND reports discuss handling and shipping of wastes generated by the EPICOR II system, an earlier radioactive waste processing system installed at TMI-2 after the accident. Appendix $A$ of this report briefly discusses EPICOR II wastes and lists GEND reports on EPICOR II waste management.

This report also contains a table on low specific activity wastes, in Appendix $B$. These wastes include trash from the Unit 2 cleanup and spent organic ion exchange resins. These low specific activity wastes are being shipped off the island for disposal at a commercial burial site. 


\section{HISTORY OF SUBMERGED DEMINERALIZER SYSTEM DEVELOPMENT}

As a result of the accident at TMI-2, GPUNC needed to decontaminate accident-generated water while minimizing the amount of waste such decontamination would yield. A demineralizer system based on the use of inorganic zeolites was considered the most promising alternative. The system eventually designed and developed to process accident water is submerged in the TMI-2 spent fuel pool and is called the Submerged Demineralizer System, or SDS.

GPUNC developed the SDS in consultation with the TMI-2 Waste Management Technical Advisory Group (TAG), a group of technical experts assembled by the U.S. Department of Energy (DOE) Technical Integration Office at TMI-2. GPUNC's subcontractors were Chem-Nuclear Systems, Inc. and Allied General Nuclear Services. The U.S. DOE provided technical assistance through the Oak Ridge National Laboratory (ORNL) and Savannah River Laboratory (SRL). These groups combined efforts to design, evaluate, and test the SDS, resulting in successful hot operations at TMI-2.

GPUNC's accident waste management efforts began with processing of water in the Unit 2 Auxiliary Building Basement using a system called EPICOR II. The EPICOR II system was designed to purify medium-specificactivity-level water. By December 1981, EPICOR II generated 50 prefilters and 22 resin liners while removing approximately 55,000 Ci from 565,000 gal

of contaminated water in the Auxiliary and Fuel Handling Buildings. EPICOR II is now used in conjunction with SOS operations as the final polishing unit.

\section{Conceptual Design}

GPUNC and the TMI-2 Waste Management TAG determined that the 650,000 gal of high specific activity water in the Reactor Building Basement, and the 90,000 gal in the Reactor Coolant System (RCS) required a demineralizer system besides EPICOR II to reconcentrate radioisotopes released from the core during the accident. The system design requirements were: 
- A totally integrated system as independent as possible from existing waste and off-gas systems at TMI

- A system that would remove the fission products in the water to levels meeting release requirements

- A system that would be operable with minimal exposure to operating personnel and pose a negligible risk to the general public

- A system that would accomplish these objectives in a timely and cost effective manner.

Tests and analyses performed by ORNL and SRL showed that these criteria could be met with a zeolite-based system. ${ }^{3}$ Personnel from both national labs worked with members of the TMI-2 TAG to develop a proposed process flowsheet. Allied General Nuclear Services designed a detailed processing system flowsheet for Chem-Nuclear Systems, Inc. based on the TMI-2 TAG flowsheet. The resulting system was designed to decontaminate high specific activity water so that the concentrations of nuclides (except tritium) would be less than $10 \%$ of the concentrations listed in 10 CFR 20 for aqueous effluents in unrestricted areas. (The 10 CFR 20 concentrations are 1 isted in Appendix $C$ of this report.)

\section{Selection of Ion Exchange Media}

To minimize waste product generation, inorganic zeolite media were selected for use instead of the organic ion exchange media used in EPICOR II. Inorganic zeolite is a molecular sieve material highly selective for electrolytic absorption of Cs and Sr from waste water.

There are two main advantages of using zeolites rather than organic resins for ion exchange beds at TMI-2. First, zeolites show good stability to doses of $10^{11}$ rads and higher, ${ }^{4}$ while organic resins are limited to integrated radiation doses of less than $10^{8}$ rads before they become 
significantly degraded (Reference 1). This stability at high doses is an important criterion in designing a system to absorb high concentrations of radioisotopes.

Second, certain kinds of zeolites have a superior selectivity for both cesium ions ( $\left.\mathrm{Cs}^{+}\right)$and strontium ions $\left(\mathrm{Sr}^{++}\right)$when processing water with high sodium ion $(\mathrm{Na}+)$ concentrations. Zeolites are hydrated silicates of aluminum and can contain either sodium or calcium or both. The sodium zeolites demonstrate the superior selectivity for $\mathrm{Cs}^{+}$and $\mathrm{Sr++} . \mathrm{Na}+$, like $\mathrm{Cs}+$ and Sr++, is also an ionic species in aqueous solution, and competes actively for absorption sites with $\mathrm{Cs}_{\mathrm{S}}$ and $\mathrm{Sr+t}$ in either organic resin or calcium zeolite media. Sodium zeolites, by reducing the absorption of $\mathrm{Na}^{+}$, reduce the total number of expended ion exchange vessels. This lowers operation and disposition costs.

To confirm these two advantages, the TAG asked ORNL to recommend which ion exchange media to use to remove the radioisotopes $\mathrm{Cs}_{S}$ and $\mathrm{Sr}$ from the TMI-2 accident-generated water. Of the many zeolites and resins tested by ORNL, the ion exchange media recommended were zeolite Linde Ionsiv IE-96 ${ }^{a}$ (formerly called AW-500) and resin HCR-S (DOWEX-50 ${ }^{b}$ ). Both were then used in flowsheet testing at ORNL. Zeolite IE-96 was selected for use in the SDS on the basis of the ORNL flowsheet tests. Later testing showed that mixing IE-96 with another zeolite called A-51 would improve Sr decontamination. This mixture was eventually used in the SDS.

Testing of Flowsheet at ORNL

The SDS flowsheet for decontamination of the water at TMI-2 was evaluated at ORNL in a study that included filtration tests, ion exchange column loading tests, and ion exchange distribution tests. 5 The tests were performed at $10^{-5}$ scale on zeolites and organic resins. The tests confirmed that the SDS flowsheet using zeolites would in fact meet the design objectives of decontaminating the water, such that if the effluents would be

\footnotetext{
a. Trademark of Union Carbide Corporation, Linde Division.

b. Trademark of Dow Chemical Company.
} 
mixed with normal plant discharges the concentrations of nuclides (except tritium) would be less than $10 \%$ of the concentrations listed in 10 CFR 20 .

The original flowsheet is shown in Figure 1 . In this flowsheet, the contaminated water would be filtered before transfer into the ion exchange feed tanks. The filtered water would then be pumped through either or both of two duplicate trains of ion exchange bed vessels. Each train consists of a series of three vessels containing zeolite Ionsiv IE-95 in the $\mathrm{Na}+$ form. The effluent from either train of zeolite vessels would then pass through one of two duplicate vessels containing an organic cation exchange resin, Nalcite HCR-S, in the H+ form. Finally, the effluent from both cation resin vessels would be combined and passed through a single large polishing vessel containing layers of cation resin (HCR-S, in the $\mathrm{H}+$ form), anion resin (Nalcite SBR, in the $\mathrm{OH}^{-}$form), and mixed resin (Nalcite $\mathrm{MR}-3$, a $1: 1$ volume mixture of HCR-S and SBR).

This original flowsheet provided for a 5-gpm flowrate through the SDS vessels. On the basis of a water residence time in each vessel corresponding to a flow rate of $5 \mathrm{gpm}$, ORNL determined that each vessel should contain 8 cubic ft of zeolite. Changeout of a zeolite ion exchange vessel was estimated to be required after every 220 to 250 vessel volumes of flow through each vesse1. System operating pressure was set between 80 to 100 psig with a design pressure of $150 \mathrm{psig}$, the maximum pressure the piping could safely withstand.

Laboratory-scale studies of the proposed SDS process recommended possible modifications to the reference SDS flowsheet for potentially improving performance by lowering the expected effluent radionuclide concentrations. 6 The most promising method for reducing the $C_{s}$ and $S r$ concentrations below $10^{-4} \mu \mathrm{Ci} / \mathrm{ml}$ was to hold (age) the zeolite vessel effluent for at least $2 \mathrm{hr}$ at $167^{\circ} \mathrm{F}$ before passing the effluent through another zeolite column. This would provide time for the colloidal (solid form) radionuclide species in the effluent to dissolve into the soluble ionic form for removal by the zeolite vessel downstream. Another suggested alternative was control of the $\mathrm{pH}$ of the water, since $\mathrm{pH}$ influences the selectivity of certain radionuclides, particularly that of $\mathrm{Sr}$. As the $\mathrm{pH}$ is lowered the colloidal, or 


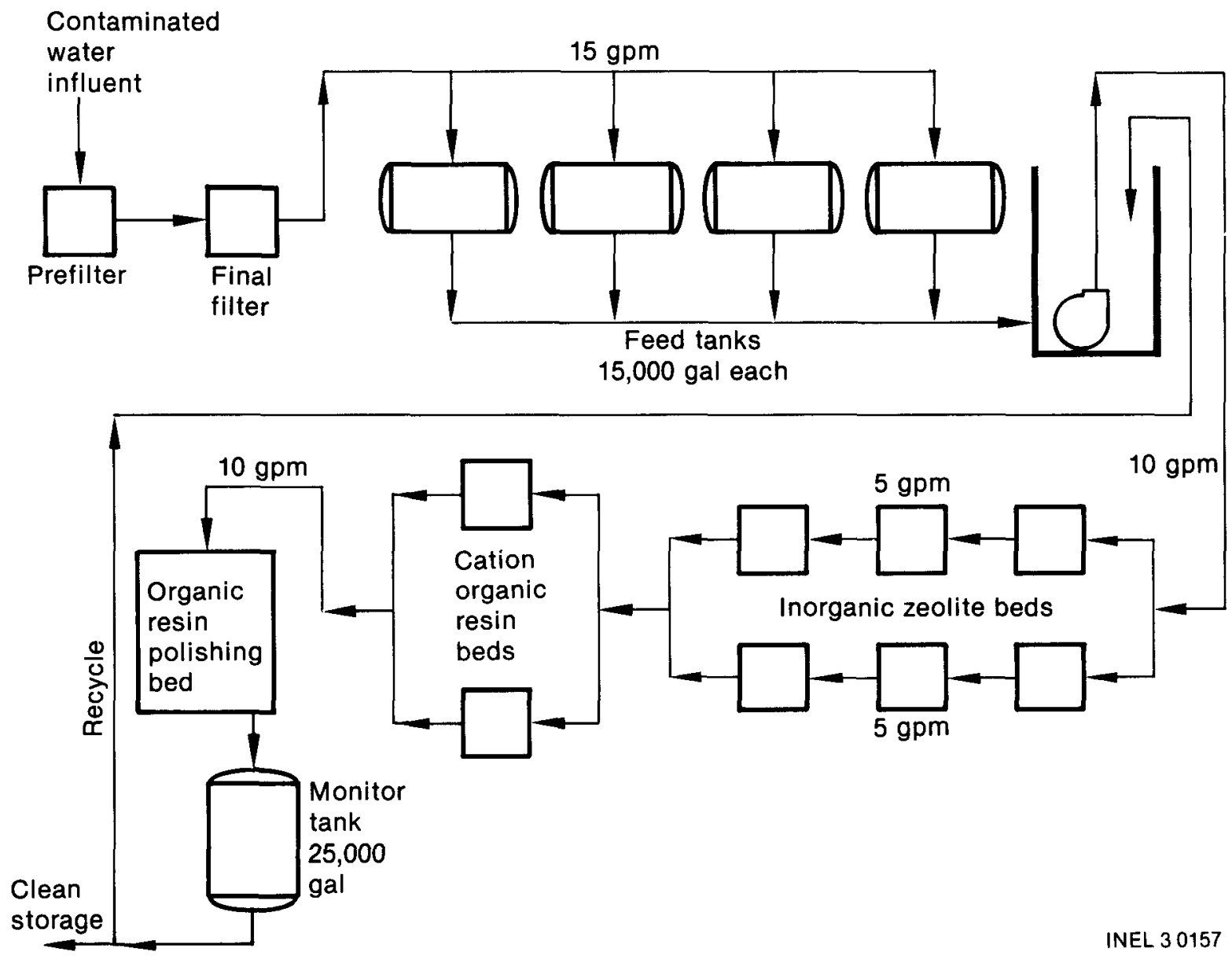

Figure 1. Original SDS flowsheet showing flowrates. 
solid, form of Sr tends to dissolve into aqueous solution. However, after further testing neither the aging process nor $\mathrm{pH}$ control proved necessary for overall SDS process efficiency in full-scale operations at TMI.

During testing at ORNL, no improved method was found for removing the anionic contaminants, ${ }^{125} \mathrm{Sb}$ and ${ }^{106} \mathrm{Ru}$. The only satisfactory method for removing these radionuclides would require deionizing the water by removing $\mathrm{Na}+$ on a cation exchange resin prior to sorption of the ${ }^{125} \mathrm{Sb}$ and ${ }^{106} \mathrm{Ru}$ on anionic exchange resins. However, such treatment was expected to generate relatively large amounts of low activity level solid waste. This solution would have been costly, and since it would not have added significantly to the system's overall efficiency in removing the trace contaminants ${ }^{125} \mathrm{Sb}$ and ${ }^{106} \mathrm{Ru}$, it was not considered prerequisite for construction and operation of the SDS system at TMI. Sb and Ru are removed effectively by treatment of SDS effluent through EPICOR II.

\section{Increased Cesium Loading Studies}

The SDS flowsheet design specification originally limited each zeolite bed to 10,000 $\mathrm{Ci}$ of $\mathrm{Cs}$ and $\mathrm{Sr}$ before vessel changeout would have been required. However, a DOE study (Reference 4), completed before system startup, evaluated the technical and financial benefits of loading each vessel to higher levels of radioactivity. The DOE study concluded that optimum loading for each vessel be 60,000 Ci of $\mathrm{Cs}$ and 2,000 Ci of Sr. The DOE study recognized that these liners could technically handle even higher levels of activity, but for reasons including safety and economics, the vessels should be limited to $60,000 \mathrm{Ci}$ of $\mathrm{Cs}_{S}$ and 2,000 Ci of $\mathrm{Sr}$. The flowsheet modifications appropriate for the new loadings permitted a volumetric throughput of about 1500 vessel volumes before changeout of a vessel was required, as opposed to 220 to 250 vessel volumes permitted in the original flowsheet. The increased loading factor was expected to reduce by a factor of 6 the expected number of vessels required to process the Reactor Building Basement water, and at the same time substantially increase their research and development value to DOE as highly loaded ion exchange media vessels. 


\section{SYSTEM DESCRIPTION}

GPUNC managed SOS construction and installation with Catalytic Inc., the craft labor subcontractor. Many of the major components of the system were designed by Permutit Inc. and Allied General Nuclear Services, built by Applied Engineering Company at their facilities, and shipped to TMI-2 for installation.

\section{System Components}

The SDS consists of the following systems, all of which are located in or around the Unit $2 A$ and $B$ spent fuel pools.

- $\quad$ Feed filtering system

- Feed tank system, or "tank farm"

- Ion exchange system

- Sampling and monitoring system

- Monitor tank system

- Off-gas and liquid separation and ventilation system.

Each system is briefly described below. A more detailed discussion of system components is available in GPUNC'S SDS design description.?

\section{Feed Filtering System}

The feed filtering system includes two filters: a pre- and final filter. As shown in Figure 2, the filter vessels are $24 \mathrm{in.}$ in diameter and 53-1/2 in. high; they have 3/8-in.-thick stainless steel walls. There are two types of filters: cellulose and sand. Cellulose cartridge filters, manufactured by the Cuno Division of AMF, Inc., were used first in the SUS. 


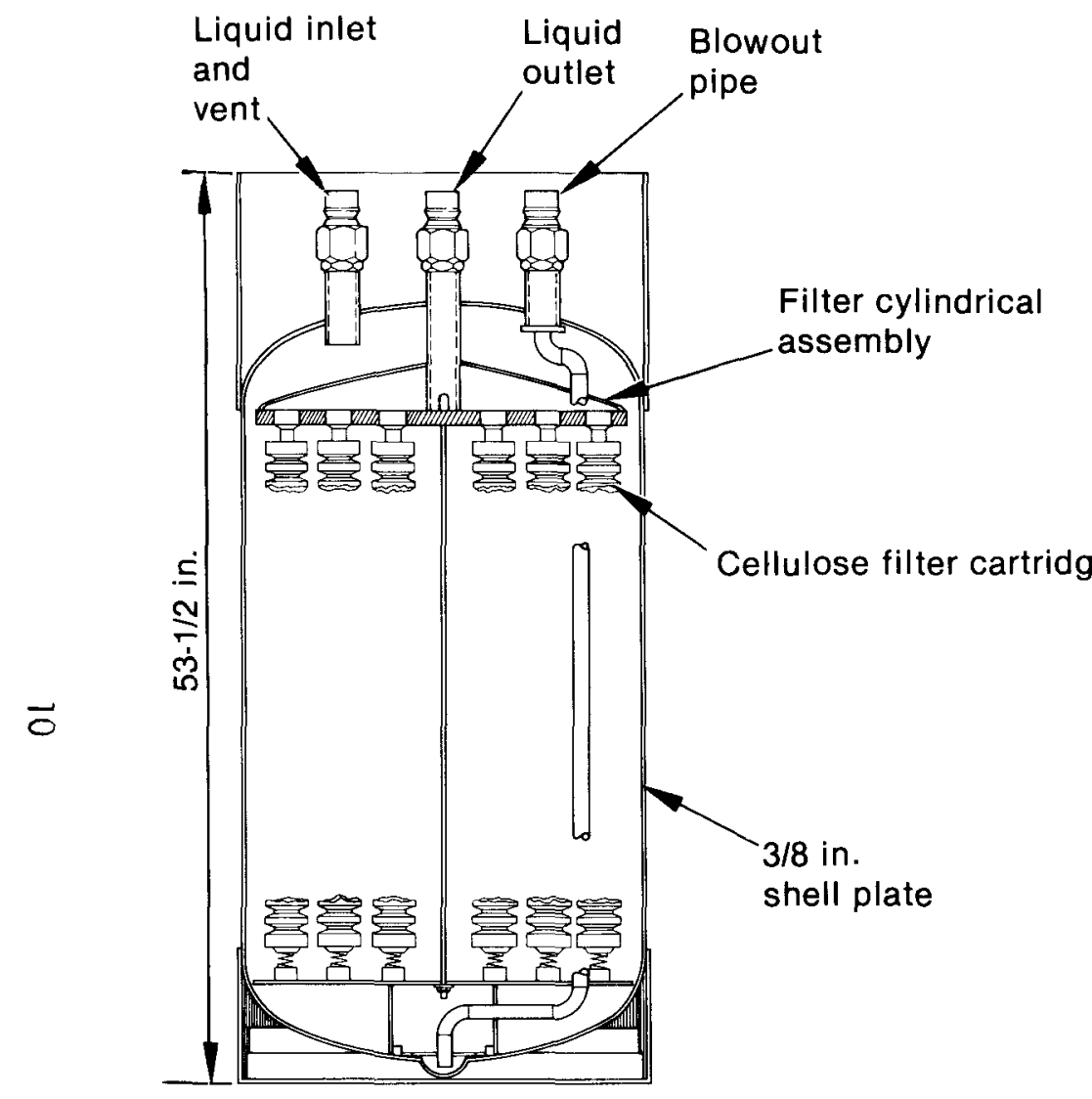

Cellulose final filter ( 6 cartridges with $10-\mu$ mesh)

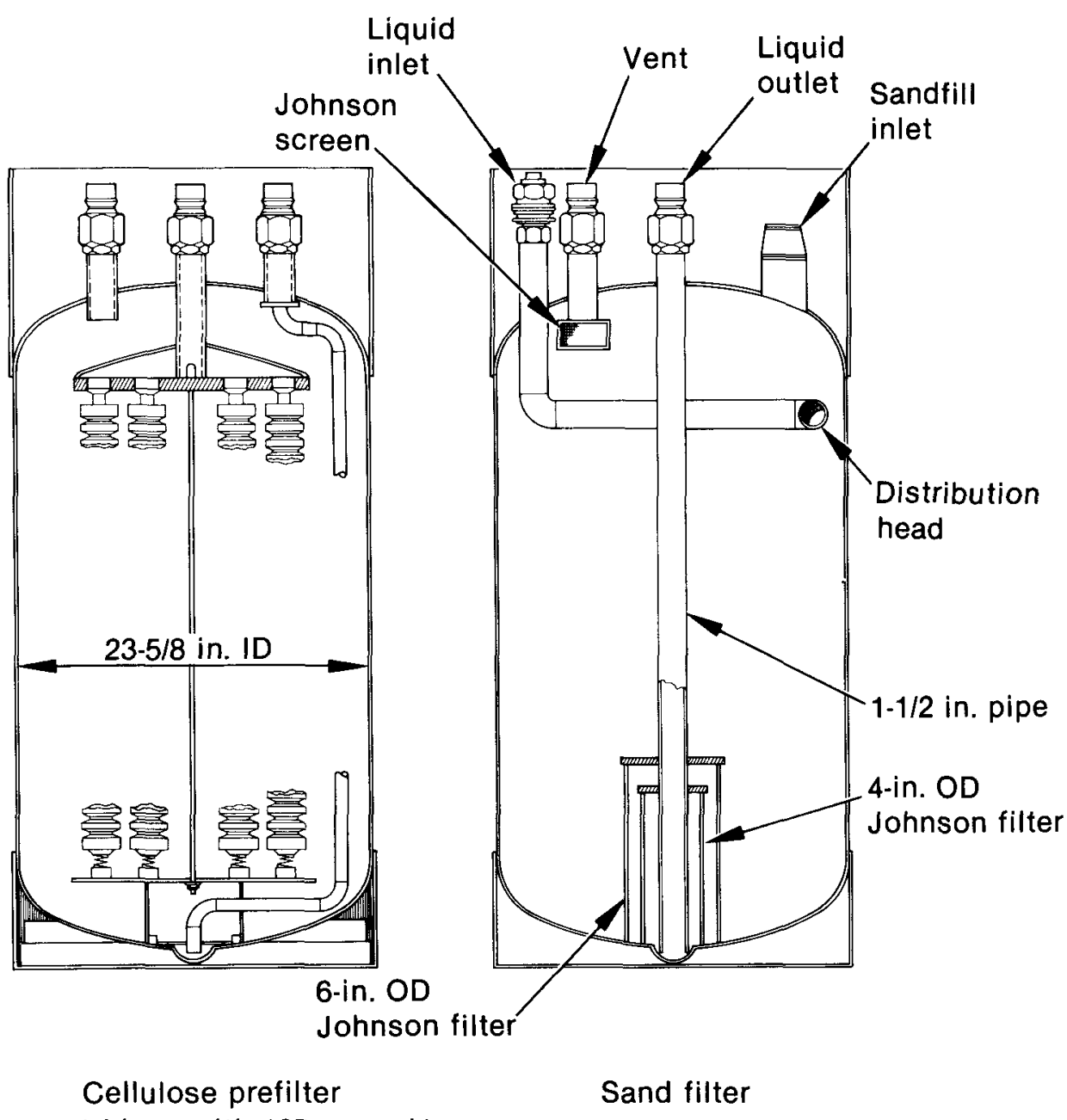

(4 cartridges with $125-\mu$ mesh)

Figure 2. Cutaway view of cellulose and sand filter vessels. 
The cellulose prefilter had $125 \mu$ mesh while the cellulose final filter had a $10 \mu$ mesh. After system functional startup testing, problems with cellulose filters during dewatering prompted a switch to sand bed filters. The cellulose filter cartridges in the prefilter weigh about 18 1b; the final filter cartridges weigh about $40 \mathrm{lb}$. Sand in each sand filter weighs approximately $900 \mathrm{lb}$. The filtering system flow rate is nominaly $25 \mathrm{gpm}$ when water flows to the tank farm. When the filtered water flows directly to the ion exchange vessels, the flowrate reflects the SDS process flow rate of $5 \mathrm{gpm}$.

\section{Tank Farm}

The SDS feed tank system, known as the tank farm, consists of four 15,000-gal storage tanks interconnected in parallel with no valves between tanks. The four tanks function as one 60,000-gal storage system. The tanks are primarily used for holding contaminated water after it has been filtered and before it is processed in the SDS ion exchange vessels. Level indicators monitor water levels in the tanks.

\section{Ion Exchange System}

The ion exchange system uses six zeolite vessels arranged in two trains. Train One consists of two vessels, one in the $1 A$ and one in the $1 B$ position, and bypass piping (jumpers) in the $I C$ and Cation $A$ positions. Train Two consists of four vessels in the 2A, 2B, $2 C$, and Cation B positions. Figure 3 shows a cutaway view of one of these vessels. They are 53-1/2 in. high and $24 \mathrm{in.}$ in diameter with 3/8-in.-thick stainless stee 1 walls. These vessels were designed to withstand $350 \mathrm{psig}$ at $400^{\circ} \mathrm{F}$ and hydrostatically tested to $540 \mathrm{psig}$. An empty vessel weighs about $730 \mathrm{lb}$, which is heavy enough to ensure that a vessel will not float even when empty. When loaded with approximately $300 \mathrm{lb}$ of zeolite and saturated with 420 ib of water, the vessel may weigh up to 1500 ib.

The ion exchange vessels were constructed by three different companies using the same design. (See Appendix D for vessel nomenclature.) Each vessel contains approximately $8 \mathrm{ft}^{3}$ of a zeolite mixture combining 


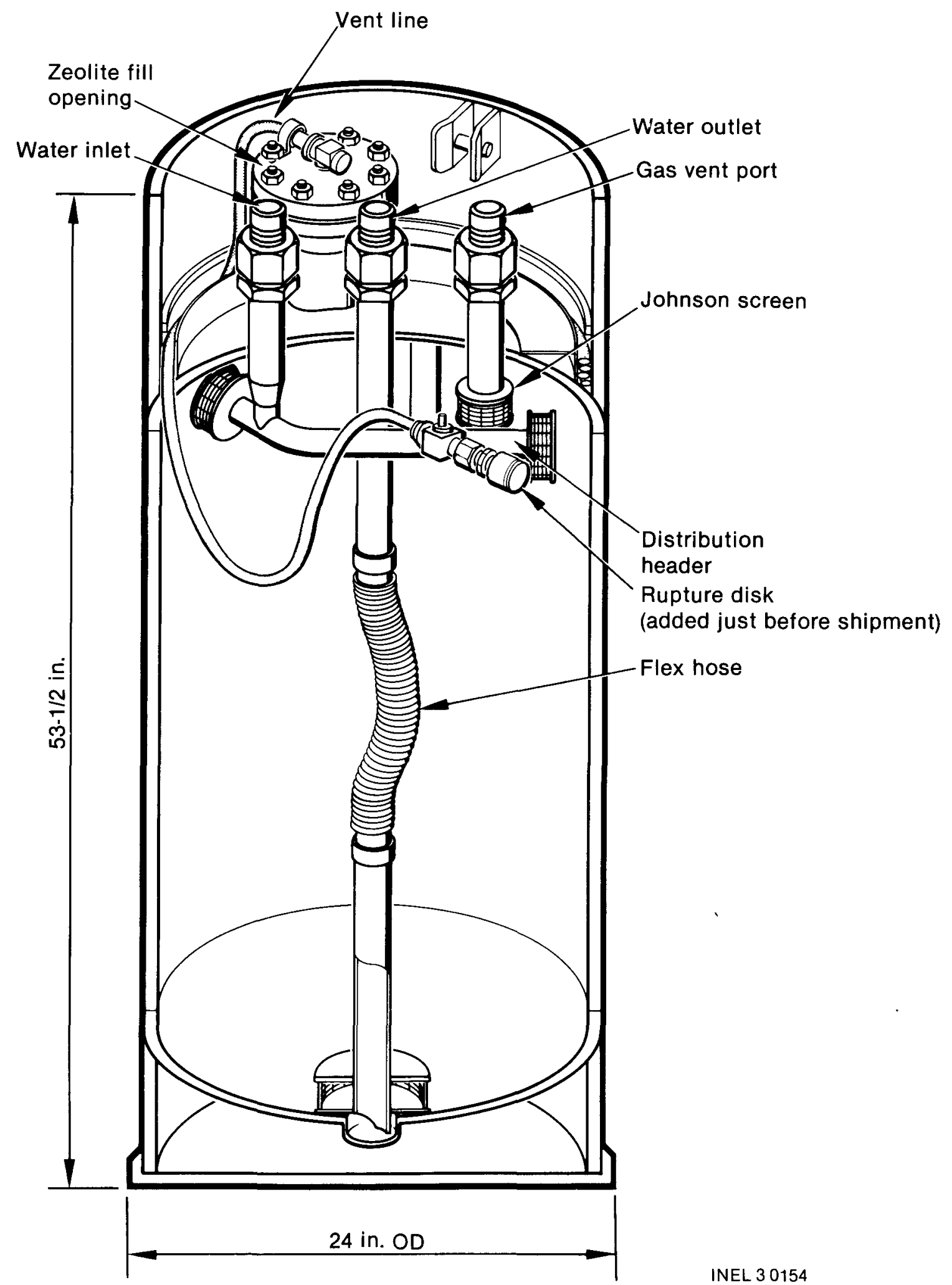

Figure 3. Cutaway view of a SDS ion exchange vesse1. 
Linde Ionsiv IE-96 with Linde Ionsiv A-5]. IE-96 is an alkali metal alumino-silicate zeolite of the chabazite structure type with the following chemical composition:

$\mathrm{Na}_{2} \mathrm{O} \cdot \mathrm{Al}_{2} \mathrm{O}_{3} \cdot 4 \mathrm{SiO}_{2} \cdot \mathrm{H}_{2} \mathrm{O} \cdot$

Ion exchange capacity of IE-96 is 2.0-2.5 meq/gm anhydrous. It has a water content of 12 to 17 wt\% in the hydrated form. 8

Linde Ionsiv A-51, a high-aluminic crystalline zeolite, has the following composition:

$\mathrm{Na}_{2} \mathrm{O} \cdot \mathrm{Al}_{2} \mathrm{O}_{3} \cdot 2 \mathrm{SiO}_{2} \cdot 4.5 \mathrm{H}_{2} \mathrm{O}$

Ion exchange capacity of A-5I is 5.0-5.5 meq/gm anhydrous, and it has a water content of 16 to $20 \mathrm{wt} \%$, hydrated (see Reference 8 ). The ratio of 1E-96 to A-51 used in each vessel is shown in Table 1. The ratios selected for use in each vessel was based on expected $\mathrm{Cs}_{s}-\mathrm{to}-\mathrm{Sr}$ ratios in the influent water. The mixtures were homogeneous.

TABLE 1. RATIOS OF ZEOLITE IE-96 TO A-5I IN SDS VESSELS

\begin{tabular}{lccc} 
& $\begin{array}{c}\text { Mix Ratio } \\
\text { IE-96:A-51 }\end{array}$ & Vessel & $\begin{array}{c}\text { Mix Ratio } \\
\text { IE-96:A-51 }\end{array}$ \\
\hline Vesse1 & $3: 2$ & D20022 & $1: 1$ \\
D10011 & $3: 2$ & D20026 & $1: 1$ \\
D10013 & $3: 2$ & 020027 & $3: 2$ \\
010014 & $3: 2$ & 020028 & $3: 2$ \\
010015 & $2: 1$ & 020029 & $3: 2$ \\
D10016 & $3: 2$ & D20031 & $3: 2$ \\
010017 & $3: 2$ & 020037 & $1: 1$ \\
D10018 & $2: 1$ & & \\
\hline
\end{tabular}


Leakage Containment. To ensure that leakage from submerged components does not introduce activity from the process streams into the pool water, SDS components are enclosed in secondary containments into which pool water is continuously drawn. Each containment is an underwater cubicle connected to a pump intake manifold which maintains a continuous flow of approximately $10 \mathrm{gpm}$ through openings in each cubicle. This flow prevents water that enters a cubicle from returning to the spent fuel pool. The combined flow from the ten containment cubicles is processed through a separate organic resin ion exchange vessel known as the leakage containment vessel. Following processing in the leakage containment vessel, the containment cubicle flush water returns to the spent fuel pool. The organic resin leakage containment ion exchange vessels are standard vessels, identical in size to the SDS zeolite vessels (see Figure 3 ).

\section{Sampling and Monitoring System}

Samples of the SOS process stream can be taken to monitor performance and estimate curie loadings on ion exchange beds at each step in the process. Figure 4 shows where in the process samples can be taken. Table 2 lists which effluent and influent lines are monitored at each sample location.

The sampling lines are connected to lead-shielded sample glove boxes where intermediate and high level radioactive samples can be taken for evaluating system performance. Sample lines $A$ and $C$ connect to the high radiation level (high rad) filter sample glove box, sample line $D$ to the high rad feed sample glove box, and lines F, G, and $H$ to the intermediate radiation level (intermediate rad) feed sample glove box. Sample line $E$ connects to both the intermediate and high rad feed glove boxes. The high rad feed and filter glove boxes have more lead shielding than the intermediate rad feed glove box and also have remotely operated spigots from which to obtain samples. 
(C)

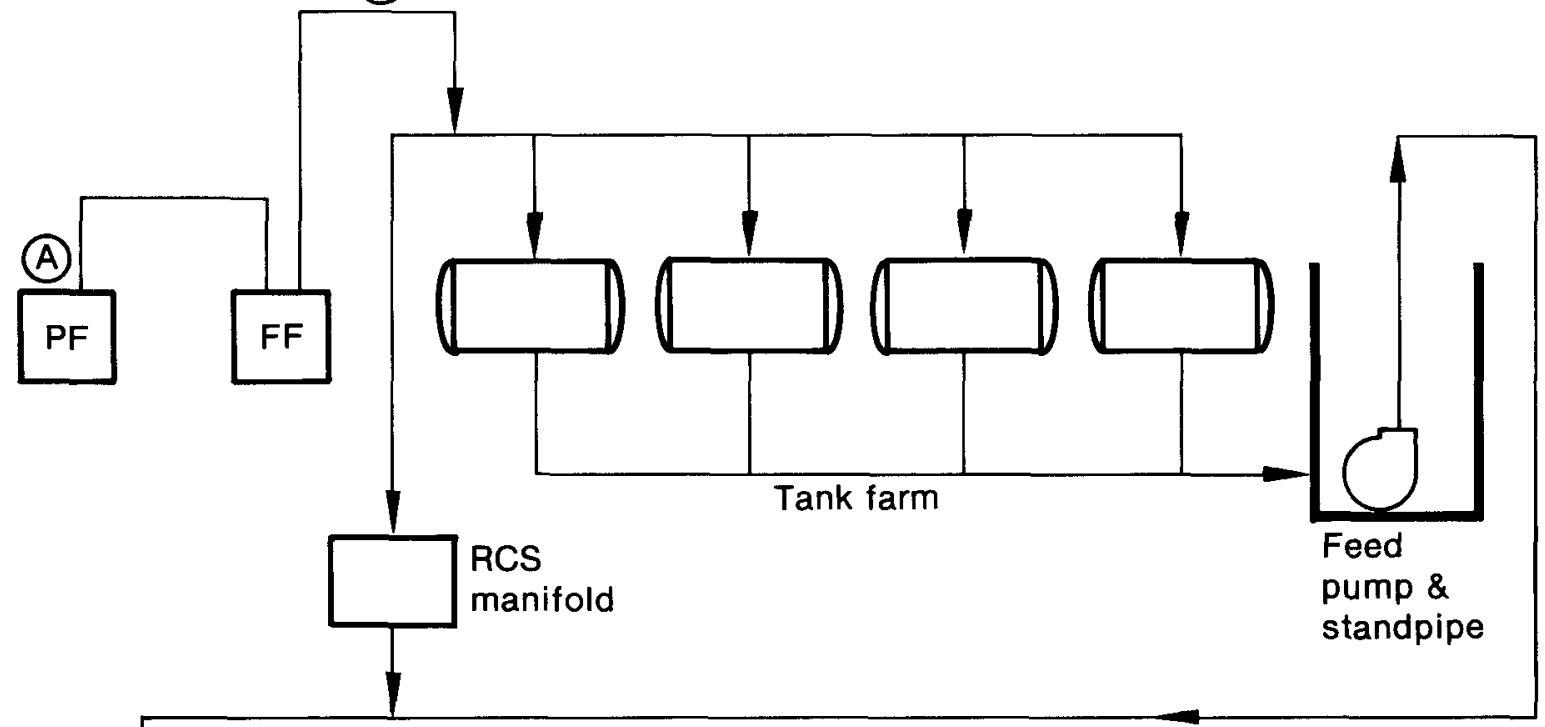

(D)

(E)

(

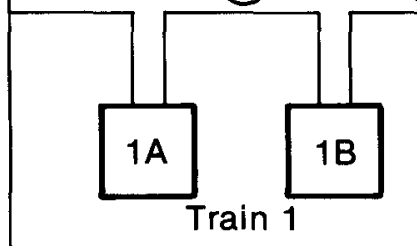

I

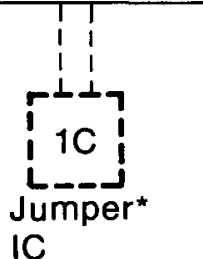

(G)

(E)

(
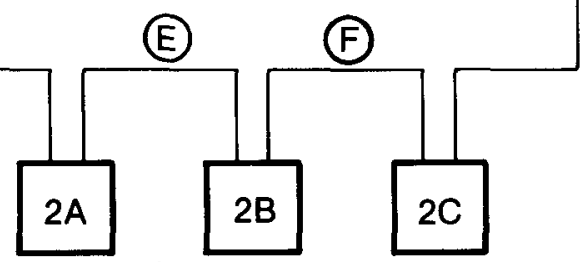

Train 2

(G)

Sample location

Glove Box

$$
\begin{aligned}
& \text { A,C } \\
& \text { D,E† } \\
& E^{\dagger}, F, G, H
\end{aligned}
$$

High rad feed

* Jumper positions $1 \mathrm{C}$ and Cat $\mathrm{A}$ could hold zeolite vessels if operators so desired.

They are normally not used.

† Sample point $E$ may be sampled from either location subject to activity level expected in sample.

Figure 4. Sampling locations for monitoring SDS operation and performance. 
TABLE 2. SAMPLE LINE LOCATIONS AND WATER STREAMS MONITORED

\begin{tabular}{|c|c|c|}
\hline $\begin{array}{c}\text { Sample } \\
\text { Location } \\
\end{array}$ & $\begin{array}{r}\text { Eff Tuent } \\
\text { Monitored }\end{array}$ & $\begin{array}{r}\text { Influent } \\
\text { Monitored }\end{array}$ \\
\hline $\begin{array}{l}A \\
C \\
D \\
E \\
F \\
G \\
H\end{array}$ & $\begin{array}{l}-- \\
\text { Filter units } \\
\text { Tank farm } \\
1 \mathrm{~A} \text { or } 2 \mathrm{~A} \\
1 \mathrm{~B} \text { or } 2 \mathrm{~B} \\
1 \mathrm{C} \text { or } 2 \mathrm{C} \\
\text { Cat } \mathrm{A} \text { or Cat } \mathrm{B}\end{array}$ & $\begin{array}{l}\text { Filter units } \\
\text { Tank farm } \\
1 A \text { or } 2 A \\
1 B \text { or } 2 B \\
1 C \text { or } 2 C \\
\text { Cat } A \text { or Cat } B \\
\text { Monitor tanks }\end{array}$ \\
\hline
\end{tabular}

Samples may also be taken at the Leakage Containment Pump and the Monitor Tank Pump Area. These locations are not part of the process stream and thus do not require special sample boxes to protect personnel from high level radiation. In addition to liquid sampling, in-line radiation detectors are available to monitor SDS processing.

\section{Monitor Tank System}

The monitor tanks are two 12,000-gal stainless steel storage vessels located in the Fuel Handling Building Model Room on the 305-ft elevation. The vessels are $8 \mathrm{ft}$ in diameter and $32 \mathrm{ft}$ high. The monitor tank system holds processed water until it is either transferred back to SDS for reprocessing or sent on to EPICOR II for polishing and eventual storage in the processed water storage tanks on the island. See Figure 5 for a schematic of water flow through the monitor tanks.

\section{Off-gas and Liquid Separation System}

An off-gas and liquid separation system collects gaseous and vaporous wastes resulting from SOS operation. The off-gas system is illustrated in Figure 6. A centrifugal blower rated at $1000 \mathrm{ft} / \mathrm{min}$ moves air through the system. Moisture condensed from the off-gas and liquid separation system is returned via the separator tank to the SDS tank farm for processing. The separator tank is located in the surge pit and is covered with a concrete and lead shield. 


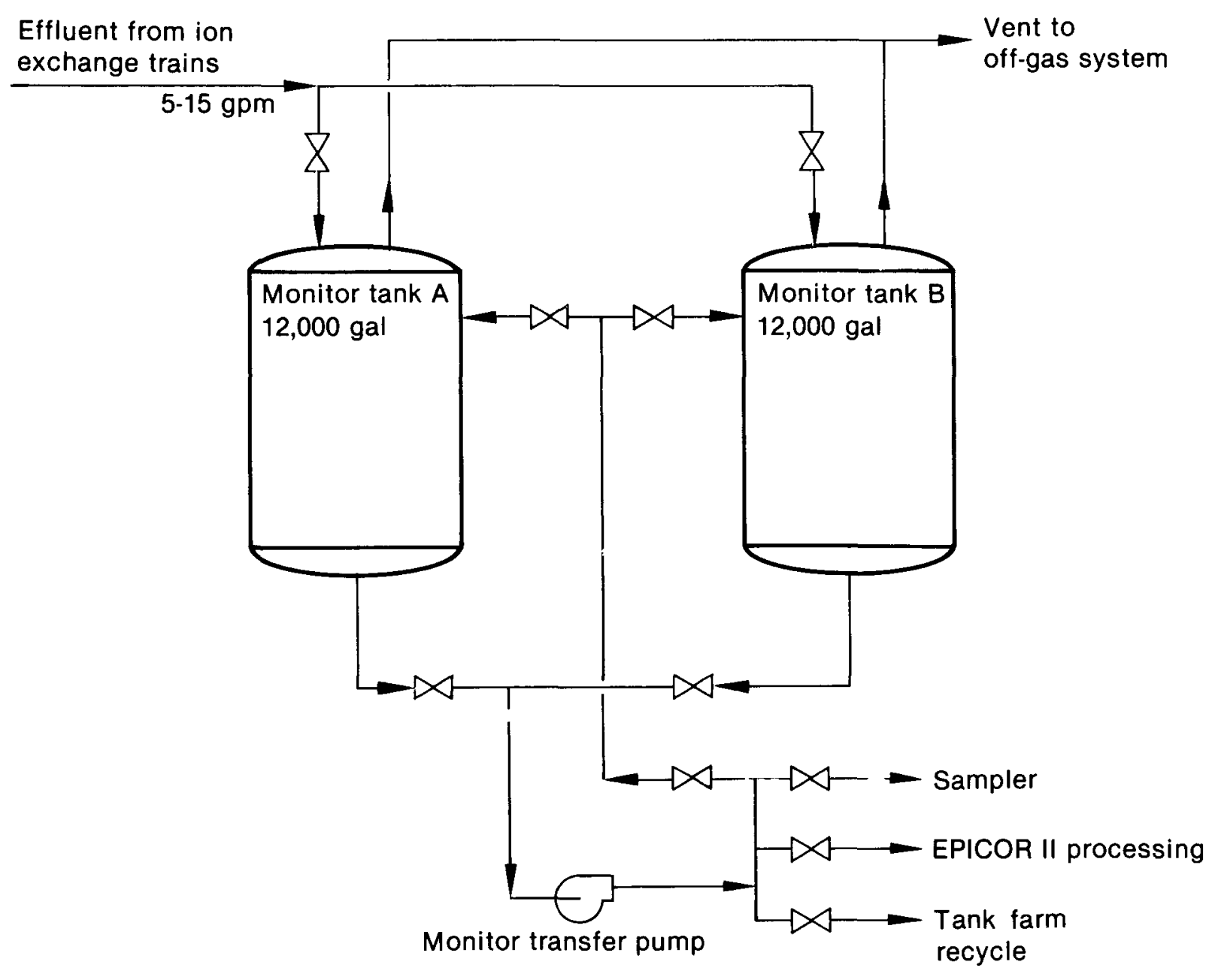

INEL 30155

Figure 5. Flowpath through the monitoring tank system. 


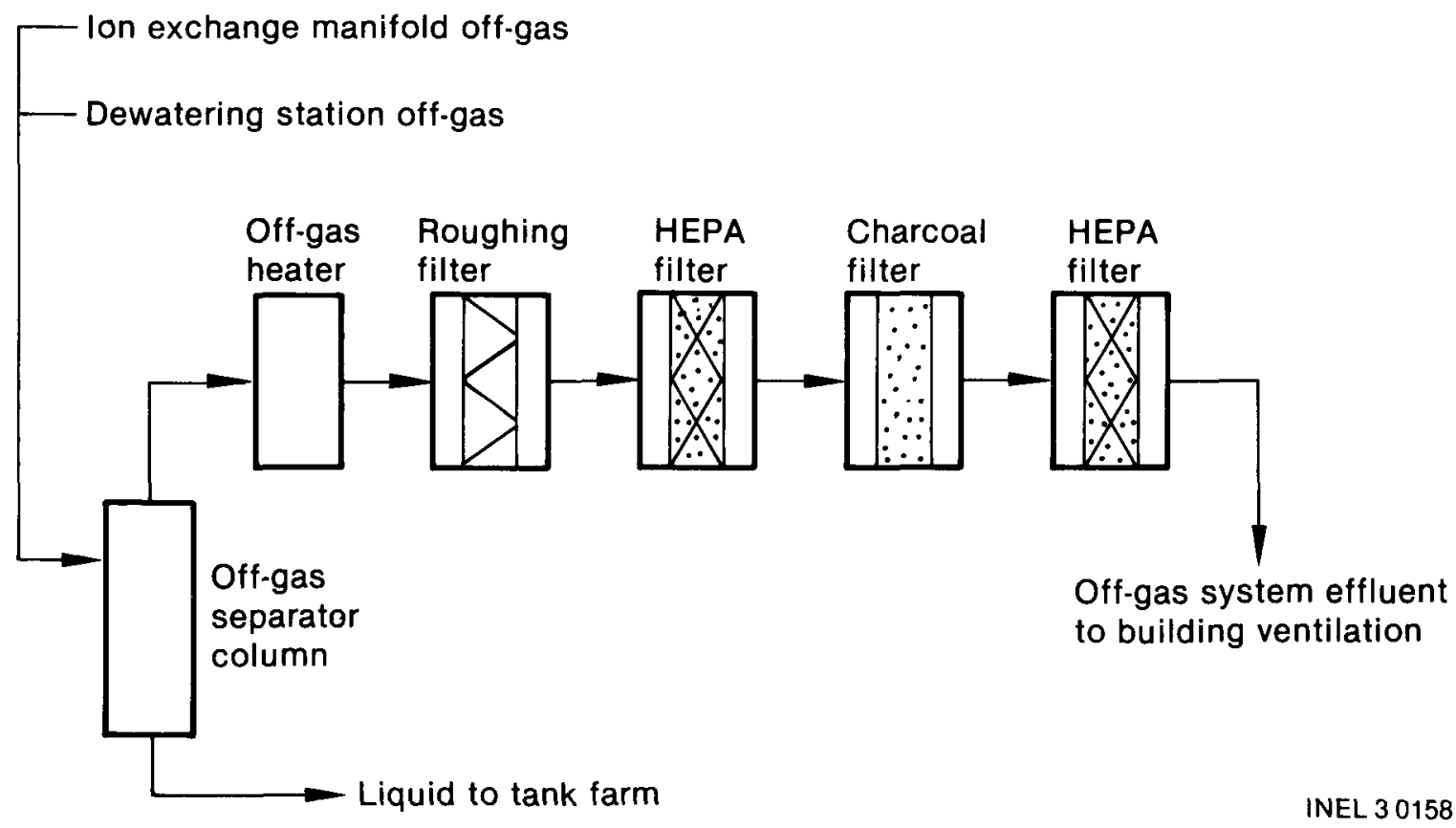

Figure 6. Off-gas and liquid separation system. 


\section{Arrangement of the System in the Spent Fuel Pool}

Figure 7 illustrates the arrangement of the SDS in the spent fuel pool as viewed from above. The tank farm is located at the south end of the fue 1 handling building in the $A$ spent fuel pool and is covered with concrete slabs. The filters and zeolite ion exchange vessels are located under water in leakage containment cubicles in the $B$ spent fuel pool. These cubicles and the exchangers rest on the pool floor and are supported along one side of the pool by a structural steel rack. The racks support the system and also provide an operating platform from which the connections to the vessels can be made remotely. The off-gas system is mounted on the curb near the surge pit area.

The dewatering station is an underwater platform in the B spent fue 1 pool cask pit and is used for removing water from expended zeolite vessels and filters by blowing nitrogen through the vessels. Dewatered vessels are then placed in an underwater storage rack that is designed to handle 60 expended vessels. This storage capacity allows SDS processing to continue without interruption until the expended vessels can be shipped from TMI-2. Stored vessels are vented through a common header connected to the off-gas and liquid separation system. This arrangement allows continual venting of gas generated in the vessels during storage.

\section{Preoperational Tests}

System testing before SDS operations began involved construction and functional tests. Construction tests determined if each system component performed as designed under normal operating conditions. These tests included checks of the system's integrity at piping interfaces and weld joints and also provided electrical continuity and component operability checks for major system components such as pumps and valves.

Functional tests were conducted once the construction tests were complete. A testing sequence was established by dividing the SUS into five 


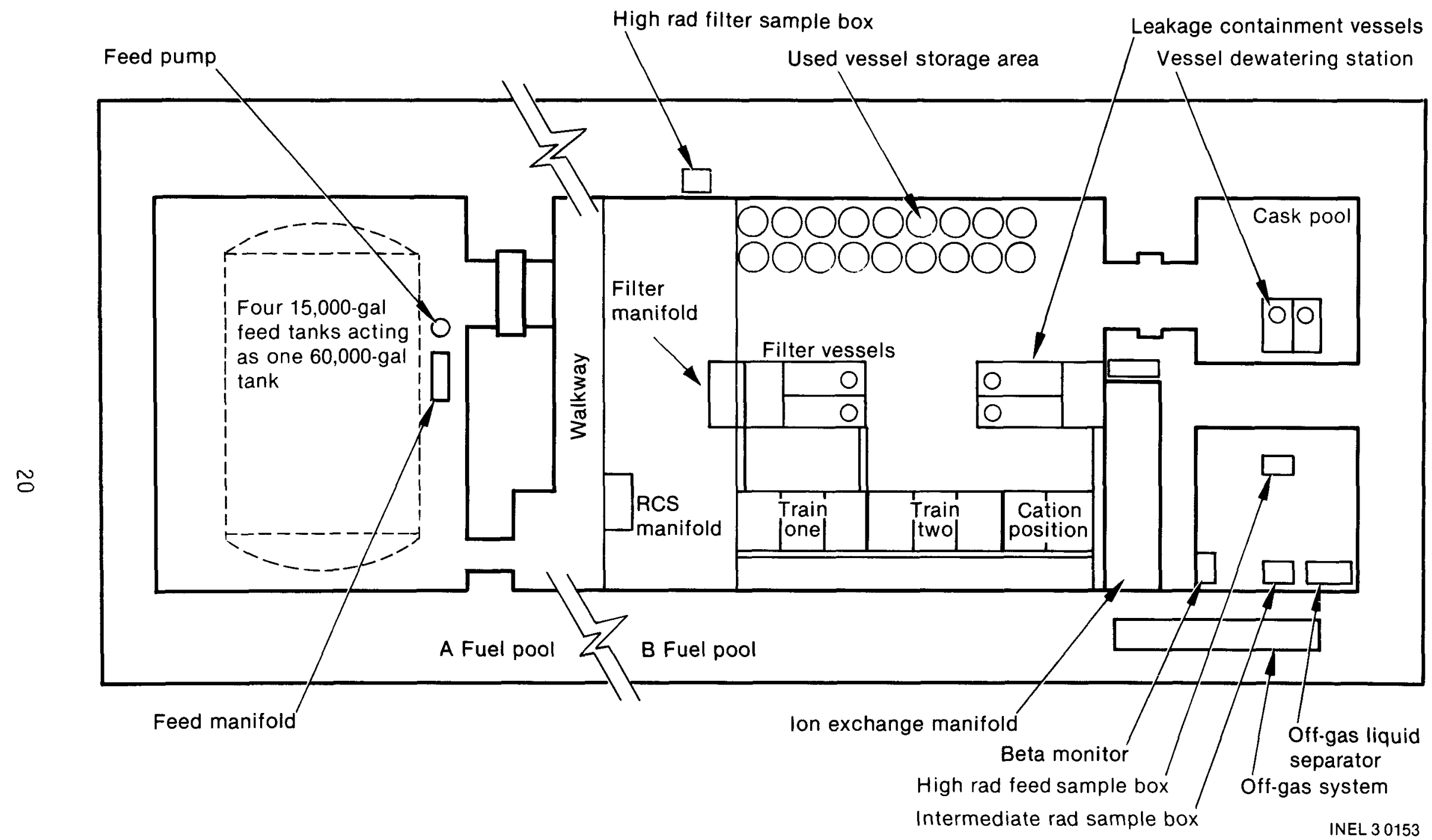

Figure 7. Arrangement of SDS components in and around the spent fuel pools. 
functional areas outlined in Figure 8. Pretests measured the performance of a portion of each functional area before major functional testing started. The functional areas were as follows:

- The off-gas system

- The ion exchange process flow system

- The monitor tank system

- The leakage containment system

- The dewatering system.

Each major functional area was tested both before and after the fuel pool was filled and the system was submerged. Hold points were established to provide adequate review before the pool was filled to ensure that prefill testing had been satisfactorily completed.

\section{System Changes}

As a result of preoperational testing and early system operations, several system changes were incorporated. The following paragraphs describe these modifications and the problems which gave rise to them.

One system sampling line ( 1 ine $E$, see Figure 4 ), monitoring the effluent of the first ion exchange bed, could possibly obtain samples that exceeded the personnel shielding capabilities of the intermediate rad feed sample glove box to which it was connected. (This possibility existed because the first bed is most likely to become expended and permit high activity waste to pass through it.) To preclude this potential problem and protect personnel in accordance with dose reduction considerations, GPUNC modified the sampling stream so that samples could be taken from a high rad feed sample glove box when levels exceeded limits of the intermediate rad feed sample glove box. 


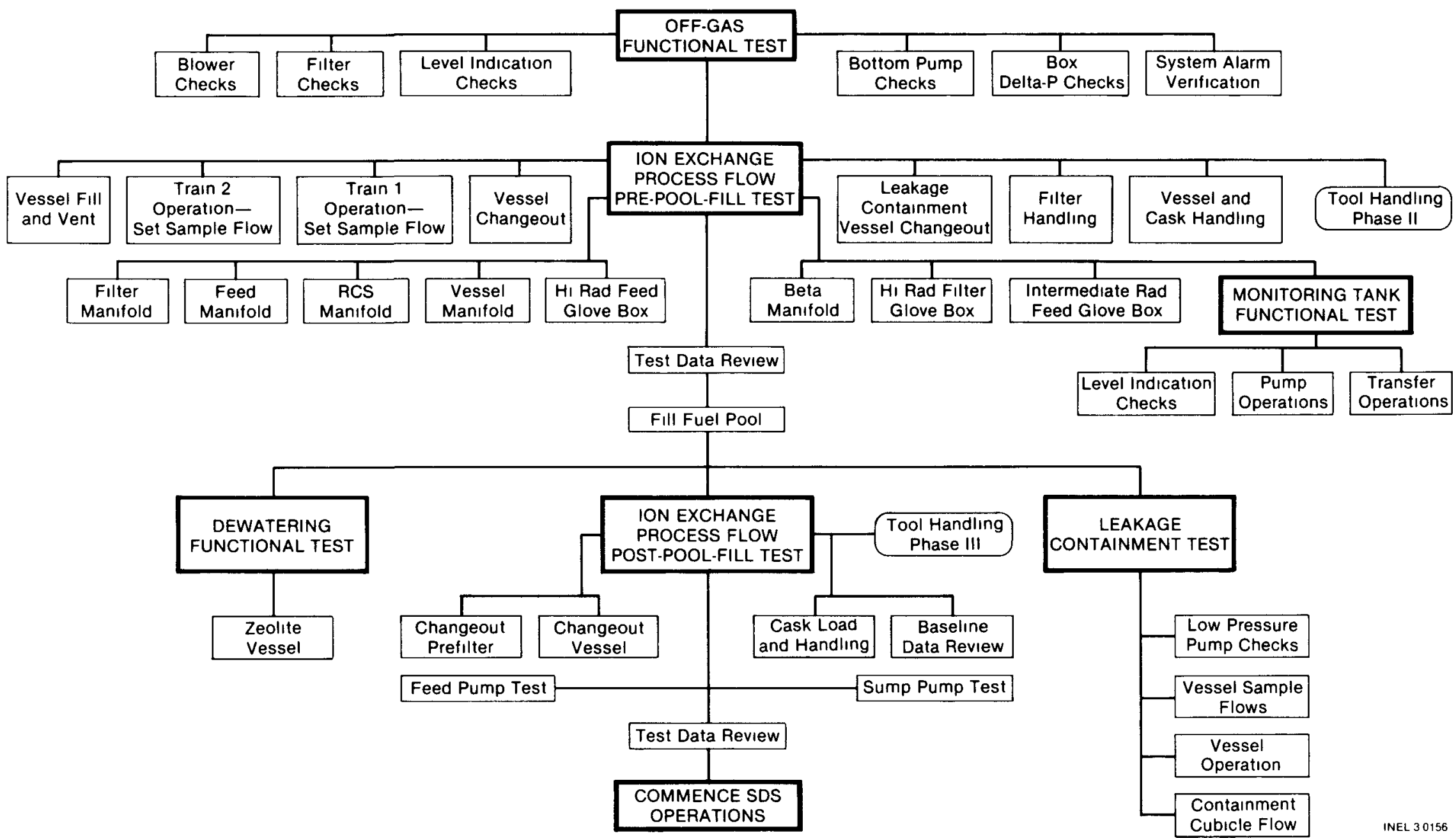

Figure 8. Functional areas testing sequence for SDS startup. 
A change was made in the procedure for controlling contamination of the monitor tanks caused by small particles of zeolites called fines. Initially, a postfilter was installed in the system between the zeolite beds and the postprocessing monitor tanks. This $3 \mu$ filter was installed to prevent zeolite fines released from new zeolite beds from excessively contaminating the monitor tanks each time a new bed was installed. However, after start of hot operations, these fines were still passing the filter in significant quantities. The new procedure addressing this problem requires flushing approximately $1000 \mathrm{gal}$ of demineralized water through each new zeolite vesse1. The vessel is then installed into the SDS and a second batch of $1000 \mathrm{gal}$ is flushed through and discharged to the $B$ Reactor Coolant Bleed Tank, to be processed at a later date. This flushing continues until sampling confirms that zeolite fines are no longer being released from the new zeolite bed. At this point, water passing through the system returns to the normal flow course.

The original flowsheet recommended that both a cation exchanger and a polishing unit be part of the SDS. The cation exchanger's primary function was to remove any residual strontium from the zeolite bed effluents. However, tests showed that the resin cation beds (HCR-S, $\mathrm{H}+$ form) readily absorb sodium ions from the contaminated water, competing directly with the strontium for exchange sites on the cationic bed. Due to the high level of sodium in the process water, the cation exchange beds were expected to become spent too quickly and would have required frequent replacement. As a result, the cation vessel was replaced by a fourth zeolite bed vessel.

The polishing unit, also recommended in the original flowsheet, was never installed. The unit would have required changeout after every 25,000 gal of water, a frequency which greatly interrupted the efficiency of the overall system. Frequent changeouts also affected personnel exposures and raised safety concerns. Installation and design engineers solved the problem by deciding to use the EPICOR II system, which was already in place. This system could not only accomplish what the polishing unit was designed to do, but could also remove the ${ }^{125} \mathrm{Sb}$ and ${ }^{106} \mathrm{Ru}$ not readily absorbable in the SDS zeolite beds. Any effluent requiring polishing was processed through the EPICOR II system. 
The filters through which the water passes before being processed in the SDS zeolite beds were originally cellulose filters. During the dewatering process, the contaminants trapped in the cellulose filters could potentially be released out of the filters. For this reason it was decided to change from cellulose to sand filters. Sand was chosen as a substitute due to its availability and lower cost, and to the fact that it did not have the same potential radionuclide release problem in dewatering as did the cellulose filters. 
The SDS was designed to process the Reactor Building Basement and Reactor Coolant System (RCS) water. It was also used to process contaminated water from the Reactor Coolant Bleed Tanks (RCBT). In conjunction with the SDS, the EPICOR II system provides final polishing for removal of trace quantities of radionuclides. Figure 9 shows the final flowsheet for the SDS process. The contaminated water passes through a pre- and final sand filter to remove particulates. Filtered water is then pumped to the ion exchange system where it is processed through a train of inorganic zeolite vessels.

The SDS ion exchange vessels are arranged in two parallel trains, with two vessels in Train One and four vessels in Train Two. Train One is reserved for RCBT and RCS water processing. Train Two is used solely for Reactor Building Basement water processing.

Once the water has passed through the ion exchange media, it travels through the postfilter and on to monitoring tanks. Water samples taken from these tanks help determine if the water needs to be returned to the SDS to be reprocessed, sent on to the EPICOR II system for final polishing, or transferred elsewhere (e.g., returned to the Bleed Tanks for storage).

Influent and effluent sample analys is and continuous in-line radiation monitoring are used to estimate curie loadings on each zeolite vessel. Actual curie loading of each vessel is controlled by feed batch size and residence time. Sample connections on the influent and effluent lines of the two filtration vessels and on the influent and effluent lines to each zeolite ion exchange bed monitor SDS efficiency and provide parameters for process control.

Samples are taken to determine radionuclide concentrations before and after each stage in the process and to determine if radionuclide breakthrough has occurred. "Breakthrough" occurs when the zeolites are spent and can no longer remove a particular radionuclide. When breakthrough occurs or when the desired curie loading is achieved on the first bed of a train, 


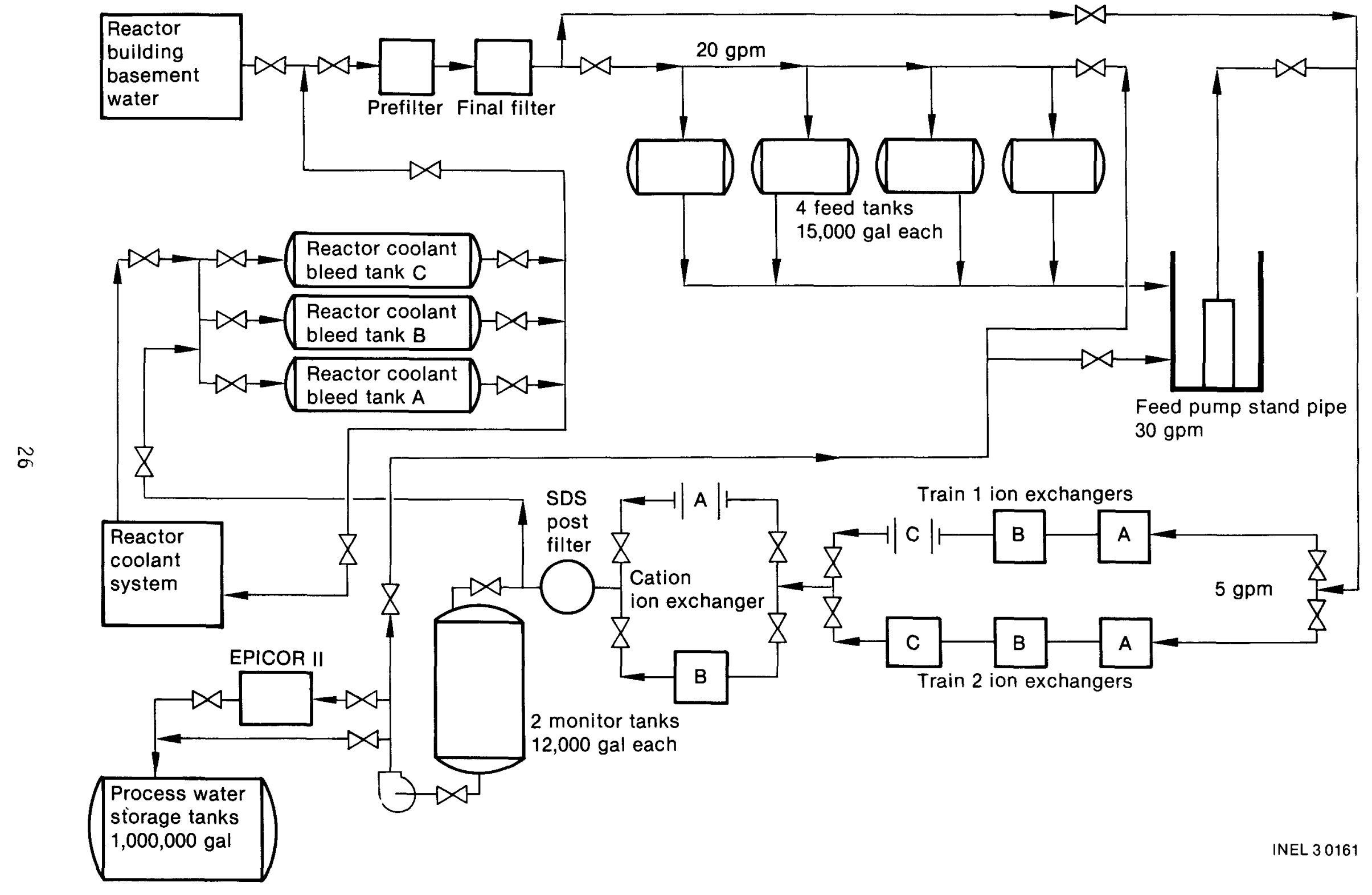

Figure 9. Final flowsheet for water processing through the SDS. 
the feed flow to the train stops, and the bed is disconnected and moved to the dewatering station and then to the storage rack in the spent fuel pool using the Fuel Handling Building crane. Downstream vessels are also disconnected and moved upstream one position. A new ion exchange vessel is then installed in the empty position as the replacement vessel. Following installation and flushing of the new ion exchange vessel, the treatment of the contaminated water recommences. This operational concept of rearranging the vessels instead of using a valving system maintains the same flowpath and eliminates the potential for valving errors. Installing a new vessel at the end of the line also minimizes the possibility of an unexpected radionuclide breakthrough, which could possibly recontaminate water already processed.

The spent SOS ion exchangers and filters remain underwater in the spent fuel pool until they are shipped. Spent ion exchange and filter vessels are loaded into a shielded transportation cask underwater and then are removed from the spent fuel pool in the cask. Once the transportation cask is sealed and decontaminated, it is loaded onto a trailer for shipment. Some of the SDS zeolite vessels will be sent to a DOE national laboratory for disposition research and development.

\section{Processing Flowpaths}

The SDS had processed water from three sources as of August 31, 1982, totaling about $1,200,000 \mathrm{gal}$, and removing approximately 650,000 $\mathrm{Ci}$. Water from each source followed process flow paths which will be discussed below.

A11 operations consisted of pumping a batch of liquid waste from the source, processing it through the SDS, and then transferring it to a receiving location. A processing batch is defined as the continuous processing of a staged amount of water through specific zeolite beds. If, during processing, a vessel requires changeout, the flow is stopped for that batch and the vessel changeout occurs. A new batch number is assigned when procossing resumes. Labelling batches in this way permits accurate record keeping for water decontamination analysis and vessel curie loading. 


\section{Reactor Coolant Bleed Tank Water Processing}

Contaminated water deposited during the accident in the RCBTs followed the flowpath shown in Figure 10 as it went through the SDS. RCBT water flowed through the prefilter and final filter to the tank farm where the water was held until it was ready to be processed. A process batch contained anywhere from 5,000 to 44,000 gal depending on processing conditions.

RCBT accident water held in the tank farm was processed through Train One containing only two ion exchange vessels. RCBT water was not as highly contaminated as Basement water and did not need to pass through four ion exchange beds in order to be decontaminated.

After passing through Train One, RCBT water went to the monitor tanks where it was either recycled to SDS for reprocessing or sent to the EPICOR II polishing demineralizers. Sampling points $A, C, D, E$, and $F$ were monitored during RCBT processing (see Figure 4). Both points $C$ and $D$ were monitored because the filtered water was held at the tank farm, which is between these two sample points, before it went through Train One of the SDS.

Reactor Building Basement Water Processing

Contaminated Basement water flowed from the Reactor Building Basement to the tank farm and was held there as was done with the original RCBT water. Its flowpath is drawn in Figure 11. Samples were obtained from points $A$ and $C$ as the Basement water flowed to the tank farm. After approximately 50,000 gal were secured in the tank farm storage system, ion exchange processing commenced through the four ion exchange vessels in Train Two. Basement water had higher activity than did the RCBT water and had to meet stricter decontamination requirements because it was to leave the Reactor Building for storage. Therefore, more ion exchange steps were required for processing the basement water. 


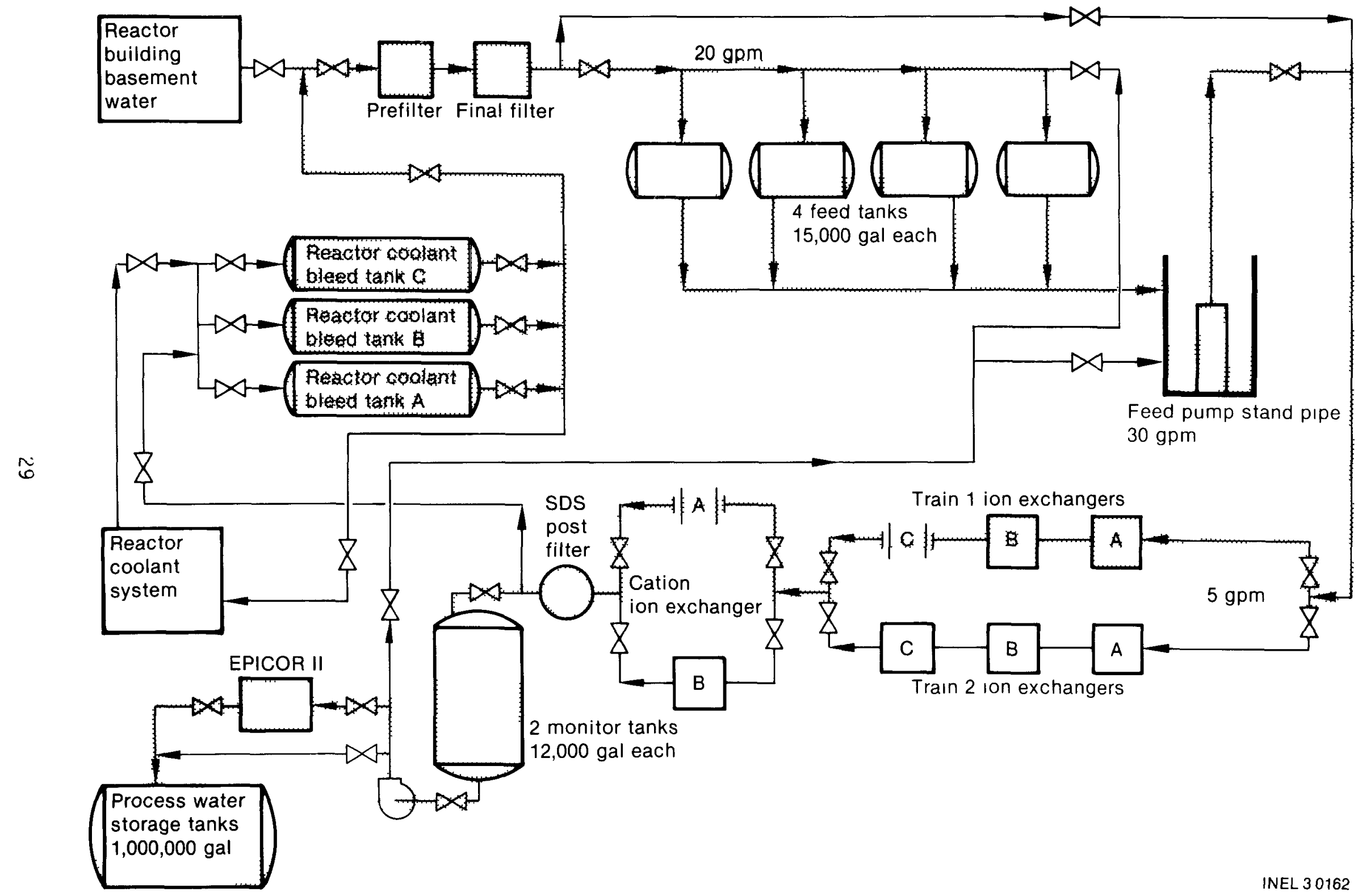

Figure 10. Final flowsheet for RCBT water processing through the SDS. 


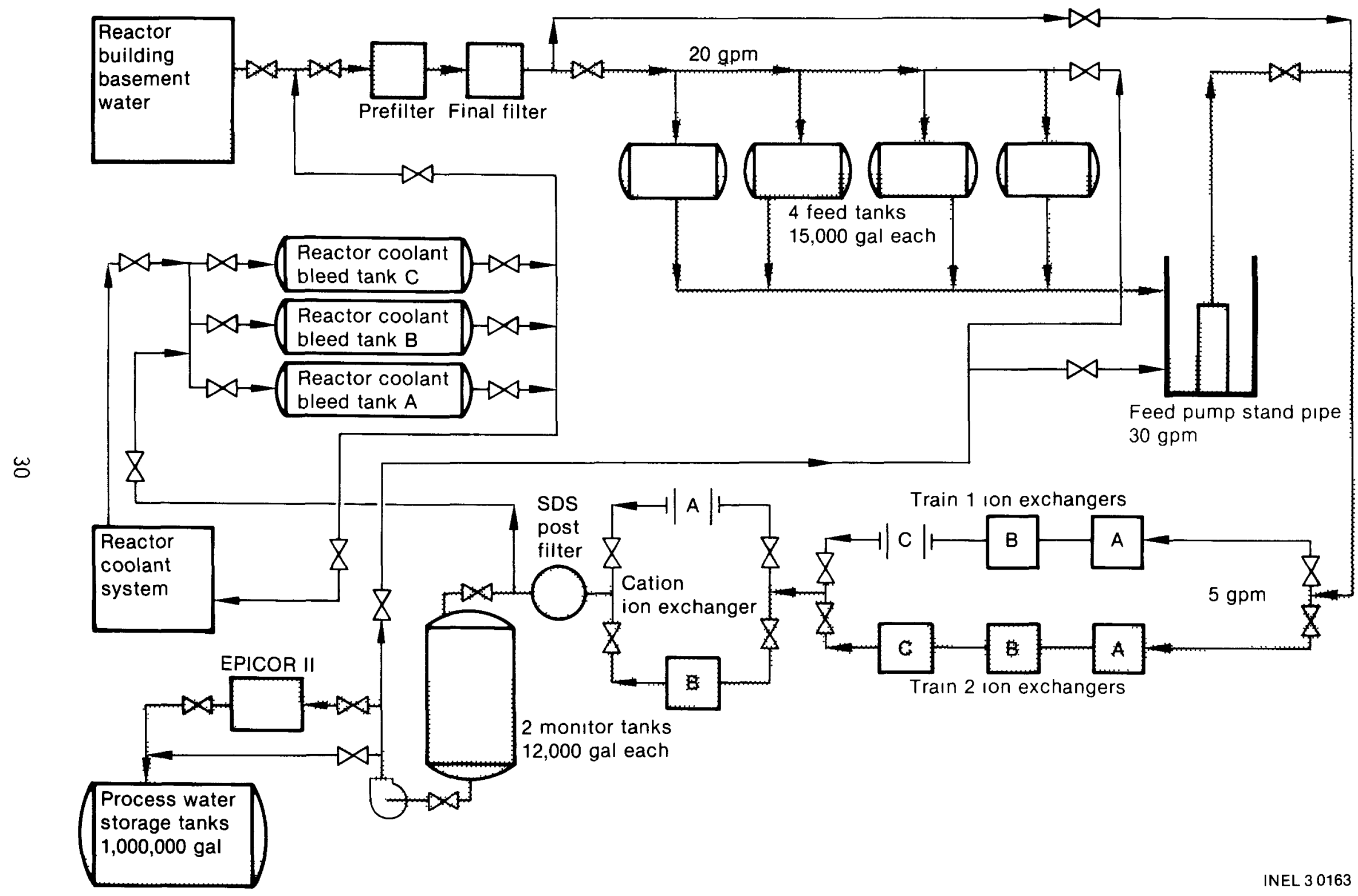

Figure 11. Final flowsheet for Reactor Building Basement water processing through the SDS. 
Since four ion exchange vesssels were used (vessel positions $2 \mathrm{~A}$ through 2C plus position Cation $B$ ), additional sampling locations were also needed. Sampling from locations $D, E, F, G$, and $H$ monitored effluent conditions. Sample results were evaluated to determine water quality and vessel curie loading.

Once the batch water was processed it was held in the monitor tank and was then either recycled or batched through the EPICOR II polishing resin beds. After EPICOR II polishing, the water was stored in the processed water storage tanks at TMI-2.

\section{Reactor Coolant System Water Processing}

RCS water processing began after processing of accident-generated basement water was complete. RCS processing uses a "feed and bleed" method: as each 50,000-gal batch of water is removed or "bled" from the RCS for processing, $50,000 \mathrm{gal}$ of processed RCS water feeds back into the RCS. This feed and bleed method keeps the RCS full and ensures that the reactor core remains covered.

The RCS processing flow path is shown in Figure 12. The RCS water is let down from the Reactor Coolant System into RCBT $C$. The water then passes through the filtration system, bypasses the tank farm, and is processed immediately by the Train One ion exchangers. Unlike RCBT and Basement water, RCS water undergoes no holding sequences at the tank farm. Samples for the RCS processing are obtained from locations A, C, E, and F. Since the water is not held in the tank farm, location $D$ is not monitored. (Samples $C$ and $D$ are essentially the same when the tank farm is bypassed.) The effluent from Train One then goes through the postfilter and on to RCBT A where it is held to be fed back into the RCS "feed and bleed" process.

\section{Radiation Protection}

The SDS was specifically designed to limit operating personnel exposure levels to as low as reasonably achievable (ALARA). The components containing high activity level water were either provided with additional shielding 


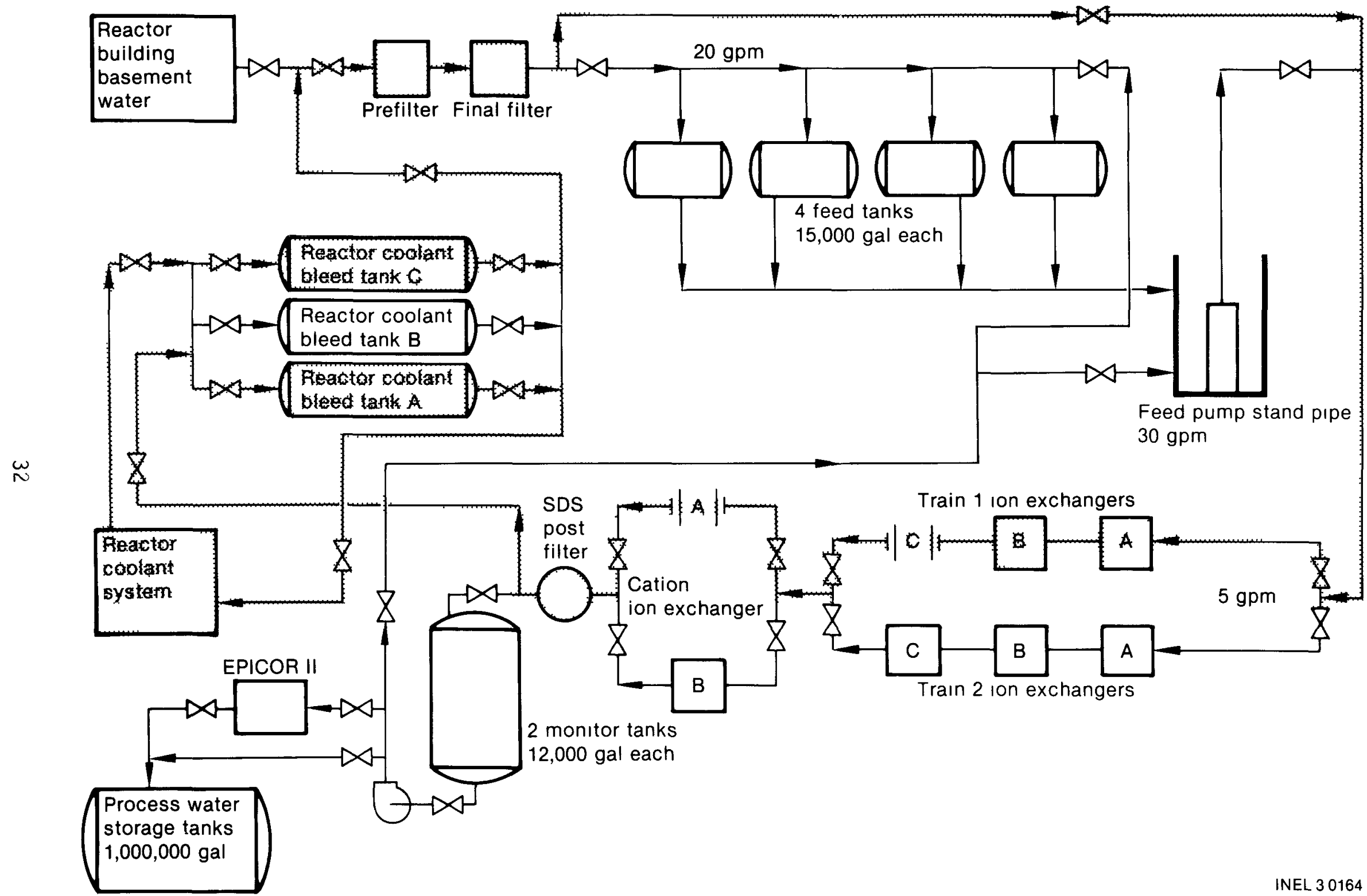

Figure 12. Final flowsheet for RCS water processing through the SUS. 
or submerged in the spent fuel pool. Shielding was designed to limit whole body exposure rates in operating areas to approximately $1 \mathrm{mR} / \mathrm{hr}$. In addition, gaseous exhaust from components carrying high activity level water was routed to the SDS off-gas system. Component shielding and off-gas treatment minimized the potential for high exposure levels and airborne releases in the work areas.

\section{Radiation Protection Design Features}

The SDS has inherent features for reduction of occupational exposures and environmental releases. The SOS is submerged in the spent fuel pool for several reasons: (a) to provide shielding during operation, (b) to permit access to the system during vessel changeout, (c) to minimize the potential hazard from possible accidents, (d) to use an existing Seismic Category I facility, and (e) to provide temporary shielded storage for the used vessels.

The Fuel Handling Building, which houses the entire SDS, is a Seismic Category I structure with air handling and ventilation systems designed to mitigate the consequences of radiological accidents. The SDS ion exchange vessels are under approximately $16 \mathrm{ft}$ of water in the TMI-2 B spent fuel pool. Where necessary for personnel protection, lead or equivalent shielding is provided for pipes, valves, and vessels not located underwater. Operating panels and instrumentation racks are located away from potential sources of radiation or are provided with adequate shielding to meet radiological exposure limits. The entire process is designed with appropriate pressure indicators and with remotely operated, valved, quick-release couplings for inlet, outlet, and vent line connections. Effluent from the offgas system, the system which filters gases generated in the SOS process, is filtered and monitored before it passes into the existing ventilation exhaust systems.

The SDS is equipped with various alarm systems (Reference 7), which warn operators of potentially hazardous conditions during normal operations or maintenance activities. The SDS is also equipped with four automatic shutdown aiarms: 
- Off-gas header influent high pressure monitor

- Ion exchange manifold general area radiation monitor

- Ion exchange manifold effluent in-line radiation monitor

- Leakage containment system influent radiation monitor.

Each of these automatic shutdown alarms can trip the Feed Isolation Valve Solenoid, which stops the water flow through the SDS, either instanteously or after a predetemined 5-to-30-minute time delay. Instantaneous closure is affected by placing the "Auto-trip" selector switch in the "Trip" position. Otherwise the Solenoid deenergizes and closes within 5 to 30 min as preset.

The SDS is designed with the primary ion exchange beds in series to preclude breakthrough and contamination of the outlet stream. Should a leak in the system occur inspite of design safety features, SDS equipment is operated within containment cubicles to prevent contamination of the spent fuel pool water.

The SDS vessels are transported out of the fuel pool in shielded transfer casks. These casks are designed to reduce radiation levels to less than $200 \mathrm{mR} / \mathrm{hr}$ on contact, in accordance with the shipping criteria found in 173.393 Title 49 of the Code of Federal Regulations.

\section{Occupational Dose}

Some SDS operations involved personnel occupational dose exposures. Major operational activities involving such exposures were as follows:

- Feed tank filling valve alignment

- Sampling operations

- System start-up valve alignment 
- Spent vessel changeout

- Cask removal, decontamination, and survey operations

- System maintenance

- Vessel dewatering.

Precautions were taken to minimize these personnel exposures. Personnel shields were tested before water from each source was processed. Test results were well within design criteria. The area readings were generally well below $0.5 \mathrm{mR} / \mathrm{hr}$, with an estimated average dose of 0.1 to $0.2 \mathrm{mR} / \mathrm{hr}$. When certain identified hot spots reached between 2 to $5 \mathrm{mR} / \mathrm{hr}$ access was restricted or the areas were shielded accordingly.

\section{Processing History}

As of August 31, 1982, over one million gals of contaminated water had been processed by SDS from the RCBT, the Reactor Building Basement, and the RCS. Uuring this processing, overall system performance met the design objective of SDS, and also decontaminated the waste water to within the limits specified in 10 CFR 20 (with the exception of limits for tritium, since the SDS could not remove tritium from the water). The composition of the contaminated water and performance of SDS in treating this water are discussed in the following section.

\section{Contamination Levels Before Processing}

Table 3 lists the concentrations and total amounts of the significant radioisotopes in the RCS and Reactor Building Basement water before SDS processing. These amounts were used in developing the original SDS processing flowsheet. The values in the table for the RCS water are composites of analytical data from several samples analyzed by ORNL. The values for the Basement water were obtained from analyzing the samples that ORNL used in the flowsheet evaluation. 
TABLE 3. COMPOSITION OF CONTAMINATED WATER BEFORE SUS PROCESSING (Values are corrected for radioactive decay to July 1, 1980)

\begin{tabular}{|c|c|c|}
\hline $\begin{array}{l}\text { System } \\
\text { Nuclide }\end{array}$ & $\begin{array}{l}\text { Reactora } \\
\text { Coolant } \\
\text { System } \\
(\mu \mathrm{Ci} / \mathrm{mL}) \\
\end{array}$ & $\begin{array}{l}\text { Reactorb } \\
\text { Building } \\
\text { Basement } \\
(\mu \mathrm{C} i / \mathrm{mL}) \\
\end{array}$ \\
\hline $3_{H}$ & 0.17 & 1.0 \\
\hline${ }^{89} \mathrm{Sr}$ & $5^{c}$ & 0.53 \\
\hline${ }^{90} \mathrm{sr}$ & $25^{C}$ & 2.3 \\
\hline${ }^{106} \mathrm{Ru}$ & 0.1 & 0.002 \\
\hline $125 \mathrm{Sb}$ & 0.01 & 0.02 \\
\hline${ }^{134} C_{s}$ & 10 & 26 \\
\hline${ }^{137} C_{s}$ & 57 & 160 \\
\hline \multirow[t]{2}{*}{${ }^{144} \mathrm{Ce}$} & 0.03 & 0.0005 \\
\hline & 97.31 & 189.8525 \\
\hline $\begin{array}{l}\text { a. Reactor Coolan } \\
\text { o. Reactor Buildi } \\
\text { c. Values vary, p }\end{array}$ & $\begin{array}{l}\text { volume i } \\
\text { ter volum } \\
\text { e of prec }\end{array}$ & $\begin{array}{l}\text { y } 90,000 \text { gal. } \\
\text { tely } 650,000 \text { gal. }\end{array}$ \\
\hline
\end{tabular}

The two most predominant radionulide contaminants were ${ }^{137}$ Cesium (half-life $=30.2 \mathrm{yrs}$ ) and ${ }^{90} \mathrm{Sr}$ (half-1 ife $=29.0 \mathrm{yrs}$ ). Both the RCS and Reactor Building waters contain sodium borate and boric acid with a $\mathrm{pH}$ of 8.2 in the RCS water and 8.6 in the Basement water. An additional contaminant is tritium (half-life $=12.3 \mathrm{yrs}$ ). This heavy isotope of hydrogen was present as tritiated water in minute concentrations after processing, which nevertheless exceeded 10 CFR 20 concentrations. The tritium was not removed by the SDS ion exchange process. It remains in the processed water stored on-site in the processed water storage tanks. 
A significant concentration of insoluble strontium was found in samples of water taken from near the Reactor Building Basement floor. In a oneliter sample, the concentration of solids in the slurry (liquid plus solids) was approximately 0.5 vol\%, as determined by centrifuging the slurry. However, both the amount and nature of the solid material in the slurry sample cannot be extrapolated to be representative of all solids in the water since the sample could be taken from only one location.

The key chemical and radiochemical constitutents in the solids from the basement sample are listed in Table 4, along with the calculated percentage of each element and nuclide in the total sample (liquid plus solid) that was insoluble. Although $\mathrm{Sr}$ was the predominant radionuclide in the solids, $92 \%$ of the $\mathrm{Sr}$ in the total sample was in the liquid phase. Essentially all of the $C_{S}$ was in the liquid phase. Thus, even if these solids were dissolved during the decontamination process, the total amount of radioactive materials in the water would not have increased significantly. The majority of the radionuclide contaminate sources were found as solute and required ion exchange methods for effective removal.

\section{Vessel Performance and Analys is}

SDS processing commenced July 12, 1981. As of August 1982, the SDS had processed 296,470 gal of RCBT water, 655,165 gal of Basement water, and $249,852 \mathrm{gal}$ of RCS water, removing a total of approximately $650,000 \mathrm{Ci}$ (on island analysis) from 1,201,487 gal of processed water. Table 5 provides the processed volume flow through each SDS vesse1. Vessel D10011, for instance, processed a total of $229,782 \mathrm{gal}$ of water before it was taken of $f$ line.

Table 6 provides a processing history by SDS batch. This is a more detailed processing history which includes results of water sample analyses for influent and effluent, decontamination factors (DF), service dates, and vessel identification numbers and processing positions during the batch. As an example, batch 5 , which commenced $9 / 22 / 81$, processed a total of 15,559 gal of Basement water through Train Two. Prefilter and final filter 
TABLE 4. SOLIDS IN ONE-LITER SAMPLE OF REACTOR BUILDING BASEMENT WATER

\begin{tabular}{|c|c|c|c|c|c|}
\hline \multicolumn{3}{|c|}{ Element Analys is } & \multicolumn{3}{|c|}{ Nuclide Analys is } \\
\hline Element & $\begin{array}{l}\text { Concentration } \\
\left(\mathrm{g} / \mathrm{mL} \text { solids } \mathrm{s}^{\mathrm{a}}\right)\end{array}$ & $\begin{array}{l}\text { Percent } \\
\text { Insoluble }\end{array}$ & Nuclide & $\begin{array}{c}\text { Concentration } \\
(\mu \mathrm{Ci} / \mathrm{mL} \text { solids } \mathrm{a}, \mathrm{c})\end{array}$ & $\begin{array}{l}\text { Percent }_{b} \\
\text { Insoluble }\end{array}$ \\
\hline $\begin{array}{l}\text { Copper } \\
\text { Nickel } \\
\text { A Tuminum }\end{array}$ & $\begin{array}{l}7500 \\
2500 \\
1450\end{array}$ & $\begin{array}{r}99 \\
\geq 98 \\
88\end{array}$ & $\begin{array}{r}90 \mathrm{Sr} \\
89 \mathrm{Sr} \\
137 \mathrm{Cs}\end{array}$ & $\begin{array}{r}38 \\
8.7 \\
4.7\end{array}$ & $\begin{array}{l}8 \\
8 \\
0.04\end{array}$ \\
\hline $\begin{array}{l}\text { Iron } \\
\text { Silicon } \\
\text { Calcium }\end{array}$ & $\begin{array}{l}850 \\
650 \\
450\end{array}$ & $\begin{array}{r}81 \\
10 \\
7\end{array}$ & $\begin{array}{l}125 \mathrm{Sb} \\
144 \mathrm{Ce} \\
134 \mathrm{Cs}\end{array}$ & $\begin{array}{l}1.5 \\
1.4 \\
0.82\end{array}$ & $\begin{array}{l}28 \\
93 \\
9.04\end{array}$ \\
\hline $\begin{array}{l}\text { Zinc } \\
\text { Chlorine } \\
\text { Magnesium }\end{array}$ & $\begin{array}{l}400 \\
400 \\
150\end{array}$ & $\begin{array}{r}>87 \\
10 \\
10\end{array}$ & $\begin{array}{r}106 \mathrm{Ru} \\
95 \mathrm{Nb} \\
60 \mathrm{Co}\end{array}$ & $\begin{array}{l}0.76 \\
0.14 \\
0.073\end{array}$ & $\begin{array}{l}66 \\
97 \\
88\end{array}$ \\
\hline $\begin{array}{l}\text { Manganese } \\
\text { Phosphorus } \\
\text { Chromium }\end{array}$ & $\begin{array}{l}90 \\
30 \\
25\end{array}$ & $\begin{array}{r}\geq 69 \\
20 \\
12\end{array}$ & $\begin{array}{r}58 \mathrm{Co} \\
103 \mathrm{Ru}\end{array}$ & $\begin{array}{l}0.020 \\
0.010\end{array}$ & $\begin{array}{l}88 \\
66\end{array}$ \\
\hline $\begin{array}{l}\text { Potassium } \\
\text { Cobalt } \\
\text { Barium }\end{array}$ & $\begin{array}{r}15 \\
3.5 \\
2.5\end{array}$ & $\begin{array}{r}1 \\
\geq 8 \\
\geq 11\end{array}$ & & & \\
\hline $\begin{array}{l}\text { Strontium } \\
\text { Cesium }\end{array}$ & $\begin{array}{l}2.5 \\
0.5\end{array}$ & $\begin{array}{l}\geq 11 \\
0.04\end{array}$ & & & \\
\hline
\end{tabular}

a. Based on volume of solids after centrifugation.

b. Percentage of element or nuclide in the total sample (liquid plus solid) that is insoluble. The Calculations are based on a total solids content of 0.5 vol in the centrifuged sample.

c. Concentration on July $1,1980$. 
TABLE 5. VOLUMETRIC FLOW THROUGH SDS VESSELS

\begin{tabular}{|c|c|c|c|}
\hline Vessel & Water Types & $\begin{array}{c}\text { Batch } \\
\text { Number } \\
\text { Processed } \\
\end{array}$ & $\begin{array}{l}\text { Volumes } \\
\text { Processed } \\
\text { (gal) }\end{array}$ \\
\hline 1 & Basement & 7,11 & $229,782^{a}$ \\
\hline D10012 & $\begin{array}{l}\text { RCBT, } \\
\text { Basement }\end{array}$ & 4,9 & $208,512^{a}$ \\
\hline D10013 & $\begin{array}{l}\text { RCBT, } \\
\text { Basement }\end{array}$ & $\begin{array}{l}4,11 \\
14,16\end{array}$ & $406,008^{a}$ \\
\hline D10014 & $\begin{array}{l}\text { Basement, } \\
\text { RCS }\end{array}$ & $\begin{array}{l}14,22 \\
33,34\end{array}$ & 371,583 \\
\hline D10015 & RCBT & $1,3,12$ & $190,518^{a}$ \\
\hline D10016 & $\begin{array}{l}\text { RCBT, } \\
\text { Basement }\end{array}$ & $\begin{array}{l}4,11 \\
14,22\end{array}$ & $616,037 a$ \\
\hline D10017 & $\begin{array}{l}\text { RCBT, } \\
\text { Basement }\end{array}$ & 5,6 & $60,870^{a}$ \\
\hline D10018 & $\begin{array}{l}\text { RCBT, } \\
\text { Basement }\end{array}$ & $\begin{array}{l}1,3,12,13 \\
22,33\end{array}$ & 287,743 \\
\hline D20022 & RCS & 34 & 18,945 \\
\hline D20023 & Basement & 23 & 20,120 \\
\hline D20026 & $\begin{array}{l}\text { Basement, } \\
\text { RCBT, RCS }\end{array}$ & $\begin{array}{l}13,23 \\
33,34\end{array}$ & 116,170 \\
\hline D20027 & $\begin{array}{l}\text { Basement, } \\
\text { RCBT, RCS }\end{array}$ & $\begin{array}{l}17,22,24 \\
26,28,30\end{array}$ & $389,455^{a}$ \\
\hline 020028 & Basement & $10,11,14,19$ & $297,034^{a}$ \\
\hline D20029 & $\begin{array}{l}\text { Basement, } \\
\text { RCBT }\end{array}$ & $\begin{array}{l}20,24 \\
26,28,30,32\end{array}$ & 409,373 \\
\hline D20031 & RCS & 31,32 & 99,336 \\
\hline
\end{tabular}


TABLE 6. SDS BATCH PROCESSING HISTORY (AS OF 8/31/82)

\begin{tabular}{|c|c|c|c|c|c|c|c|c|c|c|c|c|c|c|c|c|c|c|}
\hline \multirow[b]{2}{*}{$\begin{array}{l}\text { Batrh } \\
\text { Number } \\
\text { Neture }\end{array}$} & \multirow[b]{2}{*}{ Date } & \multirow{2}{*}{$\begin{array}{l}\text { Process } \\
\text { Flow } \\
\text { (gal) }\end{array}$} & \multirow[b]{2}{*}{$\begin{array}{r}\text { Water } \\
\text { Type } \\
\end{array}$} & \multirow[b]{2}{*}{ Prefilter } & \multirow[b]{2}{*}{$\begin{array}{l}\text { Final } \\
\text { Filter }\end{array}$} & \multicolumn{6}{|c|}{ Vesse: Position } & \multicolumn{3}{|c|}{ Influent Samples $(\mu[1 / \mathrm{ml})$} & \multicolumn{4}{|c|}{ Effluent Samples $\left(10^{-3}{ }_{\mathrm{u}} \mathrm{C} / \mathrm{m} 1\right)$} \\
\hline & & & & & & $1 A$ & $1 \mathrm{~B}$ & $2 A$ & $2 \mathrm{~B}$ & $2 C$ & Cat B & Sr & Cs & Total & Sr & Cs & Total & DF \\
\hline $\begin{array}{l}1 \\
?\end{array}$ & $\begin{array}{l}5 / 30-7 / 19 \\
7 / 27-7 / 31\end{array}$ & $\begin{array}{l}49,451 \\
43,519\end{array}$ & $\begin{array}{l}\text { RCBT } \\
\text { RCBT }\end{array}$ & $\begin{array}{l}\text { Finon? } \\
\text { Finom? }\end{array}$ & $\begin{array}{l}\text { F200011 } \\
\text { F?n001 }\end{array}$ & $\begin{array}{l}010015 \\
01(x) 15\end{array}$ & $\begin{array}{l}\text { D10018 } \\
\text { D10018 }\end{array}$ & $\begin{array}{l}-- \\
--\end{array}$ & -- & -- & -- & $\begin{array}{l}0.86 \\
0.94\end{array}$ & $\begin{array}{l}1.85 \\
1.84\end{array}$ & $\begin{array}{l}2.71 \\
2.78\end{array}$ & $\begin{array}{l}9.06 \\
3.45\end{array}$ & $\begin{array}{l}6.10 \\
9.810\end{array}$ & $\begin{array}{l}15.16 \\
13.26\end{array}$ & $\begin{array}{l}178 \\
209\end{array}$ \\
\hline 3 & $\begin{array}{l}3 / 1-3 / 9 \\
9 / 79 / 7\end{array}$ & $\begin{array}{r}49,301 \\
5,521\end{array}$ & $\begin{array}{l}\text { RCBT } \\
\text { RCBT }\end{array}$ & F1001)? & T.20001 & 010015 & 010018 & D-- & $\overrightarrow{0}+{ }_{12}$ & 010013 & 010016 & 0.44 & 0.60 & 1.04 & 7.06 & 8.180 & 15.24 & \\
\hline & $9 / 1$ पा & 5,521 & $R C B)$ & 0000018 & 000007 & & -- & $01001 /$ & $01001 ?$ & 010013 & 010016 & 0.18 & 0.47 & 0.65 & 11.51 & 1.220 & 12.72 & 51 \\
\hline 5 & $\begin{array}{l}9 / 2 ?-9 / 25 \\
9 / 26-10 / 4\end{array}$ & $15,5,59$ & Basement & F10001 & 000007 & -- & -- & 010017 & 010012 & D10013 & D10016 & 3.23 & 91.00 & 94.23 & 15.00 & 0.952 & 15.95 & 5,909 \\
\hline b & $9 / \sqrt[6]{6-10 / 4}$ & $4 h, 31$ & Basement & $F[t)(n)$ & D00007 & -- & -- & 010017 & $01001 ?$ & 010013 & 010016 & 3.18 & 112.07 & 115.85 & 12.60 & 0.870 & 13.50 & $8,5,81$ \\
\hline $\begin{array}{l}7 \\
8\end{array}$ & $\begin{array}{l}10 / 4-10 / 18 \\
10 / 18-10 / 31\end{array}$ & $\begin{array}{l}50,168 \\
44,237\end{array}$ & Basement & Fionol & 000007 & - & -- & 010012 & D10011 & 010013 & $010 \cap 16$ & 3.91 & 112.58 & 116.48 & 15.60 & 1.036 & 16.70 & $\begin{array}{r}6,975 \\
6,99 ?\end{array}$ \\
\hline & $10 / 18-10 / 31$ & 44,737 & Bacement & Flo001 & D0000)7 & - & -- & 010012 & D10011 & 010013 & D10016 & 4.19 & 114.05 & 118.24 & 8.71 & 0.683 & 9.39 & 12,592 \\
\hline 9 & $10 / 31-11 / 9$ & $\begin{array}{r}7,070 \\
40,646\end{array}$ & $\begin{array}{l}\text { RCBT } \\
\text { Basement }\end{array}$ & $F 10001$ & D00007 & - & -- & D10012 & D10011 & 010013 & 010016 & 2.85 & 86.13 & 88.98 & 7.36 & 0.844 & 8.21 & 10,838 \\
\hline 10 & $11 / 10-11 / 19$ & 41,213 & Basement & F10001 & 000007 & $-\cdots$ & -- & D10011 & 010013 & 020028 & 010016 & 5.13 & 116.79 & 121.91 & 8.76 & 0.927 & 9.70 & 17,568 \\
\hline 11 & $11 / 20-11 / 28$ & 43,448 & Basement & F10001 & 000007 & - & -70 & 010011 & 010013 & $0200 ? 8$ & 010016 & 4.69 & 111.20 & 115.89 & 9.17 & 0.790 & 9.96 & 11,635 \\
\hline $1 ?$ & $11 / 28-12 / 9$ & 43,247 & RCBT & F1nกn1 & 000007 & D10015 & D10018 & -- & -- & -- & -- & 0.92 & 20.70 & 21.62 & 22.50 & 0.362 & 26.17 & 828 \\
\hline $\begin{array}{l}13 \\
14\end{array}$ & $\begin{array}{l}12 / 9-12 / 18 \\
12 / 19-12 / 27\end{array}$ & $\begin{array}{l}44,331 \\
44,699\end{array}$ & $\begin{array}{l}\text { RCBT } \\
\text { Basement }\end{array}$ & $\begin{array}{l}F 10001 \\
000002\end{array}$ & $\begin{array}{l}000007 \\
000009\end{array}$ & D10018 & 020026 & 010013 & $02 \overline{0028}$ & Dion & $\overrightarrow{0}-\overline{0014}$ & 0.59 & 6.23 & 6.83 & 20.94 & 0.576 & 26.70 & $2,25,6$ \\
\hline 15 & & 269 & Basement & Do000? & & $\ldots$ & -- & & & & & & & & & & & \\
\hline 16 & $1 / 6-1 / 10$ & 21,867 & Basement & Dunn? & 000009 & -- & -- & D10013 & 020028 & 010016 & 010014 & 2.49 & 84.25 & 86.74 & 7.38 & 1.037 & 8.42 & $10,30 ?$ \\
\hline 17 & $1 / 10-1 / 29$ & 44,764 & Basement & D0000? & 000009 & -- & -- & D20028 & D10016 & D10014 & 020027 & 3.02 & 103.24 & 106.27 & 7.57 & 0.986 & 8.55 & 12,429 \\
\hline 14 & $1 / 30-7 / 6$ & 43,789 & Basement & onono? & 000009 & -- & -- & 020028 & D10016 & D10014 & D20027 & 4.18 & 122.18 & 126.37 & 6.68 & 0.681 & 7.36 & 17,170 \\
\hline 19 & $2 / 7-2 / 9$ & 10,935 & Basement & Donon? & 000009 & - & -- & D20028 & 010016 & D10014 & 020027 & 4.80 & 127.00 & 131.80 & 6.38 & 0.604 & 6.98 & 18,883 \\
\hline 20 & $2 / 10-2 / 16$ & 33,498 & Basement & Dovolo? & 000009 & -- & $-\cdots$ & D10016 & D10014 & $02002 i$ & D20029 & 4.36 & 117.40 & 121.76 & 6.15 & 0.788 & 6.94 & 17,545 \\
\hline$? 1$ & $2 / 17-2 / 27$ & 43,844 & Basement & noune? & D000019 & -- & -- & D10016 & 010014 & D20027 & 020029 & 4.43 & & & 5.97 & 0.727 & 6.69 & 19,921 \\
\hline 27 & $2 / 17-3 / 5$ & 33,149 & Basement & $00000 ?$ & 000009 & -. & -- & D10016 & 010014 & 020027 & D2חก29 & 4.71 & 135.70 & 140.41 & 5.67 & 0.596 & 6.27 & 22,394 \\
\hline
\end{tabular}


TABLE 6. (Continued)

\begin{tabular}{|c|c|c|c|c|c|c|c|c|c|c|c|c|c|c|c|c|c|c|}
\hline \multirow[b]{2}{*}{$\begin{array}{l}\text { Catch } \\
\text { Number }\end{array}$} & \multirow[b]{2}{*}{ Date } & \multirow{2}{*}{$\begin{array}{l}\text { Process } \\
\text { Flow } \\
\text { (gal) } \\
\end{array}$} & \multirow[b]{2}{*}{$\begin{array}{c}\text { Water } \\
\text { Type }\end{array}$} & \multirow[b]{2}{*}{ Prefilter } & \multirow[b]{2}{*}{$\begin{array}{l}\text { Final } \\
\text { Filter }\end{array}$} & \multicolumn{6}{|c|}{ Vessel Position } & \multicolumn{3}{|c|}{ Inf luent Samples $(\mu \mathrm{Ci} / \mathrm{ml})$} & \multicolumn{4}{|c|}{ Effluent Samples $\left(10^{-3}{ }_{\omega} C_{1} / / m l\right)$} \\
\hline & & & & & & $1 A$ & $1 B$ & $2 \mathrm{~A}$ & $2 B$ & $2 C$ & Cat B & $5 r$ & Cs & Total & Sr & Cs & Iotal & DF \\
\hline 23 & $3 / 9-3 / 12$ & 20,120 & RCBT & Doono? & 000009 & 010018 & 020026 & $\ldots$ & -- & -- & D20023 & 0.88 & 15.34 & 16.22 & 13.67 & 14.730 & 27.90 & 581 \\
\hline 24 & $4 / 28-4 / 29$ & 10,901 & RCBT & boovo? & D00009 & $0 ? 0027$ & 020029 & -- & -- & -- & $\ldots$ & 0.06 & 1.53 & 1.59 & 7.53 & 0.910 & 8.44 & 188 \\
\hline $25^{3}$ & $4 / 30-6 / 2$ & -. & Basement & $00000 ?$ & 000009 & -- & -- & -- & -- & $\ldots$ & -- & $\ldots$ & -- & -. & -- & -- & -- & -- \\
\hline 26 & $5 / 4-5 / 8$ & $18,0 \cap 9$ & RCBI & 400001 & 600002 & D20027 & D20029 & -- & - & -- & -- & 0.06 & 1.01 & 1.07 & 9.80 & 1.55 & 11.35 & 94 \\
\hline 27 & $5 / 21-5 / 29$ & 50,152 & RCS & Unonol & U0000? & 020027 & 020029 & -- & -- & -. & -- & 9.15 & 10.40 & 19.55 & 46.70 & 0.942 & 47.60 & 411 \\
\hline 23 & $6 / 5-6 / 12$ & 50,240 & RCS & $\begin{array}{l}\text { U00001 } 1^{b} \\
\text { v00004 }\end{array}$ & v0000? & D20027 & 020029 & -- & -- & -- & -- & 8.43 & 7.40 & 15.84 & 42.50 & 0.883 & 51.30 & 309 \\
\hline $29 \mathrm{a}$ & $6 / 14-6 / 14$ & -- & Basement & Un0004 & 100000? & -- & -- & -- & -- & $\ldots$ & -- & $\ldots$ & -- & -- & -- & -- & -- & $\ldots$ \\
\hline 30 & $6 / 19-6 / 25$ & 50,124 & RCS & $020030^{C}$ & $020034 \mathrm{C}$ & D20027 & 020029 & -- & -- & -- & - & 9.71 & 3.98 & 13.70 & 26.77 & 0.613 & 27.40 & 500 \\
\hline 31 & $7 / 1-7 / 9$ & 51,284 & RCS & D?20030 & 020034 & D?0029 & 020031 & -. & -- & -- & -- & 8.03 & 4.89 & 12.92 & 41.80 & 0.508 & 42.30 & 305 \\
\hline 32 & $7 / 19-7 / 26$ & 48,052 & RCS & 1120030 & 020034 & 020029 & 020031 & -- & -- & - & -- & 10.26 & 3.28 & 13.54 & 32.93 & 0.466 & 33.40 & 405 \\
\hline 33 & $8 / 19-8 / 24$ & 32,774 & Basement & -- & -- & -- & -- & D10014 & 010018 & 020026 & -- & 7.00 & 106.70 & 113.70 & 24.00 & 3.00 & 27.00 & 4211 \\
\hline 34 & $8 / 27-8 / 30$ & 18,945 & Basement & -. & -- & -. & $\ldots$ & D10014 & 010018 & D70026 & -- & 5.32 & 76.20 & 81.52 & 7.80 & 2.80 & 10.10 & 8071 \\
\hline
\end{tabular}

a. Batch 25 and 29 were combined after filtration and processed as batches 33 and 34.

b. Liner v00001 was replaced by 1 iner U00004 part wav through batch 23 due to excessively high differential pressure.

c. Modifled lan-exchange vessal used as a filter. 
vessels were $F 10001$ and 000007 respectively. Ion exchange vessels were D10017, D10012, and D10013 for positions 2A, 2B, and 2C respectively. 010016 occupied the Cation $B$ position. The average influent radioactivity for batch 5 was $94.23 \mu \mathrm{Ci} / \mathrm{ml}$ and the average effluent was $15.95 \times 10^{-3} \mu \mathrm{Ci} / \mathrm{m}$ ] for a total DF of 5908. Batches 25 and 29 were staged from the Basement, filtered, and were combined into batches 33 and 34 .

SDS zeolite liner loadings were limited to $60,000 \mathrm{Cj}$ of $\mathrm{Cs}$ and $2000 \mathrm{Cj}$ of $\mathrm{Sr}$ (see Reference 3). Table 7 provides the spent liner curie estimates for $C_{s}, S r$, and their daughter products. The table also forecasts curie estimates for liners still in use as of August 31, 1982. At no time have the liner loading criteria been exceeded for $\mathrm{Cs}$ and $\mathrm{Sr}$.

Design objectives of SDS were satisfied and decontamination criteria set forth in 10 CFR 20 were attained. Overall system performance has been good, with an average RCS/RCBT decontamination factor of 507 and an average Basement water decontamination factor of 13,248 . The decontamination factor is the ratio of the radionuclide concentration in the process feed solution to its concentration in the product solution.

Sand and Cellulose Filter Analys is

The sand and cellulose filter vessels are a part of the SUS pre- and final filtration system. The process flow history of the filters are found in Table 8, which shows the total volumetric flow through each filter as of August 31, 1982. Filter vesse1 000009, for instance, filtered a total of $362,137 \mathrm{gal}$ of water before it was taken off line.

Cellulose cartridge filters were no longer used after GPUNC discovered that the filters could potentially release radioactive filtrate during the cartridge dewatering process. Sand filters composed of various grain sizes as listed in Table 9 were used as replacements for the cellulose filters. Table 10 provides the radioisotope on-island analysis estimates of each expended cellulose or sand filter. 
TABLE 7. CURIE LOADINGS ON SDS ZEOLITE LINERS AFTER PROCESSING (As of $8 / 31 / 82$ )

\begin{tabular}{|c|c|c|c|c|c|c|}
\hline \multirow[b]{2}{*}{$\begin{array}{l}\text { Liner } \\
\text { Number }\end{array}$} & \multirow[b]{2}{*}{$\begin{array}{l}\text { Water } \\
\text { Type }\end{array}$} & \multicolumn{4}{|c|}{ Curie Loading } & \multirow[b]{2}{*}{$\begin{array}{r}\text { TRUa } \\
\mathrm{nCi} / \mathrm{g} \\
\end{array}$} \\
\hline & & $\begin{array}{c}C s \\
(134,137) \\
\end{array}$ & Sr & $\begin{array}{l}\text { Total } \\
\text { Cs+Sr } \\
\end{array}$ & $\begin{array}{c}\text { Total } \\
\text { w/Daughters } \\
\end{array}$ & \\
\hline $\begin{array}{l}D 10015 \\
D 10017\end{array}$ & $\begin{array}{l}\text { RCBT } \\
\text { Easement }\end{array}$ & $\begin{array}{r}5,767 \\
30,312\end{array}$ & $\begin{array}{l}1,012 \\
1,021\end{array}$ & $\begin{array}{r}6,779 \\
31,333\end{array}$ & $\begin{array}{l}12,896 \\
59,549\end{array}$ & $\begin{array}{l}0.130 \\
9.893 E-2\end{array}$ \\
\hline $\begin{array}{l}010012 \\
010011\end{array}$ & $\begin{array}{l}\text { Basement } \\
\text { Basement }\end{array}$ & $\begin{array}{l}57,176 \\
44,317\end{array}$ & $\begin{array}{l}2,003 \\
2,061\end{array}$ & $\begin{array}{l}59,179 \\
46,378\end{array}$ & $\begin{array}{r}112,635 \\
88,158\end{array}$ & $\begin{array}{l}0.244 \\
0.178\end{array}$ \\
\hline $\begin{array}{l}D 10013 \\
D 20028\end{array}$ & $\begin{array}{l}\text { Basement } \\
\text { Basement }\end{array}$ & $\begin{array}{l}49,281 \\
43,333\end{array}$ & $\begin{array}{l}1,974 \\
1,660\end{array}$ & $\begin{array}{l}51,255 \\
44,993\end{array}$ & $\begin{array}{l}97,151 \\
86,334\end{array}$ & $\begin{array}{l}0.385 \\
0.1414\end{array}$ \\
\hline $\begin{array}{l}010016 \\
020027^{b}\end{array}$ & $\begin{array}{l}\text { Basement } \\
\text { Basement/RCS }\end{array}$ & $\begin{array}{r}57,156 \\
4,289\end{array}$ & $\begin{array}{l}1,869 \\
5,096\end{array}$ & $\begin{array}{r}59,025 \\
9,385\end{array}$ & $\begin{array}{r}112,622 \\
18,380\end{array}$ & $\begin{array}{l}7.136 \\
--\end{array}$ \\
\hline $\begin{array}{l}\text { D20029C } \\
\text { D20031C }\end{array}$ & $\begin{array}{l}\text { RCS } \\
\text { RCS }\end{array}$ & -- & -- & -- & $\begin{array}{l}12,000 \\
<3,000\end{array}$ & -- \\
\hline $\begin{array}{l}\text { D10014C } \\
\text { D10018C }\end{array}$ & $\begin{array}{l}\mathrm{RCS} \\
\mathrm{RCS}\end{array}$ & -- & -- & -- & $\begin{array}{l}30,000 \\
12,000\end{array}$ & -- \\
\hline$D \angle 0026^{C}$ & $\mathrm{RCS} / \mathrm{RCBT}$ & -- & -- & -- & $<3,000$ & -- \\
\hline \multicolumn{7}{|c|}{$\begin{array}{l}\text { a. Total TRU curie content provided by GPUNC. Converts into nanocuries } \\
\text { per gram. Assumes } 338 \text { lb of zeolite in each ijner at } 10 \% \text { water content } \\
\text { (dry weight basis). } \\
\text { b. D20027 calculations are a result of on-island analysis only. These } \\
\text { estimates may vary as much as } \pm 15 \% \text { when compared with off-island analysis } \\
\text { when available. All other values are the result of off-island analysis. }\end{array}$} \\
\hline
\end{tabular}


TABLE 8. VOLUMETRIC FLOW THROUGH SAND AND CELLULOSE FILTERS

\begin{tabular}{|c|c|c|c|c|}
\hline Filter & $\begin{array}{l}\text { Filter } \\
\text { Type }\end{array}$ & $\begin{array}{l}\text { Water } \\
\text { Type }\end{array}$ & $\begin{array}{c}\text { Batch } \\
\text { Number } \\
\text { Processed } \\
\end{array}$ & $\begin{array}{c}\text { Volume Through } \\
\text { (gal) }\end{array}$ \\
\hline F 10002 & $\begin{array}{l}\text { Cellulose } \\
\text { Prefilter }\end{array}$ & RCBT & $1-3$ & 158,276 \\
\hline 000005 & $\begin{array}{l}\text { Sand } \\
\text { Prefilter }\end{array}$ & RCBT & 4 & 2,759 \\
\hline F10001 & $\begin{array}{l}\text { Cellulose } \\
\text { Prefilter }\end{array}$ & $\begin{array}{l}\text { Basement } \\
\text { RCBT }\end{array}$ & $5-13$ & 384,627 \\
\hline D00002 & $\begin{array}{l}\text { Sand } \\
\text { Prefilter }\end{array}$ & Basement & $14-23,25$ & 362,238 \\
\hline UU0001 & $\begin{array}{l}\text { Sand } \\
\text { Prefilter }\end{array}$ & RCS & 27,28 & 104,635 \\
\hline U00004 & $\begin{array}{l}\text { Sand } \\
\text { Prefilter }\end{array}$ & RCS & $29-32$ & 55,233 \\
\hline D20030 & $\begin{array}{l}\text { Sand } \\
\text { Prefilter }\end{array}$ & RCS & $30-32$ & 153,885 \\
\hline$F 20001$ & $\begin{array}{l}\text { Cellulose } \\
\text { Final filter }\end{array}$ & RCBT & $1-3$ & 158,276 \\
\hline 000007 & $\begin{array}{l}\text { Sand } \\
\text { Final filter }\end{array}$ & $\begin{array}{l}\text { RCBT } \\
\text { Basement }\end{array}$ & $4,5-13$ & 387,386 \\
\hline D00009 & $\begin{array}{l}\text { Sand } \\
\text { Final filter }\end{array}$ & Basement & $14-23,25$ & 362,137 \\
\hline U00002 & $\begin{array}{l}\text { Sand } \\
\text { Final filter }\end{array}$ & RCS & $27-32$ & 263,238 \\
\hline
\end{tabular}


TABLE 9. SAND FILTER CONTENTS BY GRAIN PARTICLE SIZE

\begin{tabular}{|c|c|c|c|c|c|c|c|c|c|}
\hline \multirow{2}{*}{$\begin{array}{c}\text { Particle } \\
\text { Size } \\
(\mathrm{mm}) \\
\end{array}$} & \multicolumn{9}{|c|}{ Sand Filter Volumes in Cubic Feet ${ }^{a}$} \\
\hline & $\underline{U} 00001$ & U00002 & U00004 & D00002 & D00005 & D00007 & D00009 & D20030 & D20034 \\
\hline 1.20 & 2 & 2 & 3 & 0 & 0 & 0 & 0 & 3 & 0 \\
\hline 0.85 & 1 & 1 & 3 & 2 & $2001 \mathrm{bs}$ & $2001 \mathrm{bs}$ & 2 & 3 & 3 \\
\hline 0.45 & $\underline{6}$ & $\underline{6}$ & $\underline{3}$ & 7.2 & $700 \mathrm{lbs}$ & $700 \quad 1 \mathrm{bs}$ & 7.2 & $\underline{3}$ & $\underline{6}$ \\
\hline & 9 & 9 & 9 & 9.2 & 900 lbs & 900 lbs & 9.2 & 9 & 9 \\
\hline
\end{tabular}

a. Volumes are in cubic feet unless otherwise indicated. 


\begin{tabular}{|c|c|c|c|c|c|c|c|}
\hline \multirow[b]{2}{*}{ Liner } & \multirow[b]{2}{*}{ Type } & \multirow[b]{2}{*}{ Batches } & \multirow[b]{2}{*}{ Medja wt } & \multirow[b]{2}{*}{$\begin{array}{r}137 \\
(C i) \\
\end{array}$} & \multicolumn{2}{|c|}{$\begin{array}{c}\text { Estimated Curie Contentb } \\
\text { at Shipment } \\
\end{array}$} & \multirow[b]{2}{*}{$\begin{array}{c}\text { TRUC } \\
(\mathrm{nC} i / \mathrm{gm}) \\
\end{array}$} \\
\hline & & & & & $\begin{array}{r}90 \\
(\mathrm{Cr} \\
\mathrm{C}\end{array}$ & $\begin{array}{r}\text { Total } \\
(C i)\end{array}$ & \\
\hline $\begin{array}{l}F 10002 \\
F 20001\end{array}$ & $\begin{array}{l}C, P F \\
C, F F\end{array}$ & $\begin{array}{l}1-3 \\
1-3\end{array}$ & $\begin{array}{r}8165 \\
17962\end{array}$ & $\begin{array}{l}5.3 \\
0.2\end{array}$ & $\begin{array}{l}9.5 \\
3.3 E-1\end{array}$ & $\begin{array}{r}29.4 \\
1.0\end{array}$ & $\begin{array}{l}4.8 E+3 \\
2.2 E+3\end{array}$ \\
\hline $\begin{array}{l}\text { D00005 } \\
\text { D00007 }\end{array}$ & $\begin{array}{l}S, P F \\
S, F F\end{array}$ & $\begin{array}{l}4 \\
4-13\end{array}$ & $\begin{array}{l}317513 \\
317513\end{array}$ & $\begin{array}{l}9.4 \\
9.4\end{array}$ & $22 . \overline{4}$ & $\overline{65.0}$ & $\begin{array}{l}-- \\
--\end{array}$ \\
\hline $\begin{array}{l}F 10001 \\
D 00002\end{array}$ & $\begin{array}{l}C, P F \\
S, P F\end{array}$ & $\begin{array}{l}5-13 \\
14-25\end{array}$ & $\begin{array}{r}8165 \\
419117\end{array}$ & $\begin{array}{r}15.8 \\
330.2\end{array}$ & $\begin{array}{r}37.5 \\
384.4\end{array}$ & $\begin{array}{r}108.8 \\
1466.1\end{array}$ & --.7 \\
\hline $\begin{array}{l}\text { D00009 } \\
\text { U00001 }\end{array}$ & $\begin{array}{l}S, F F \\
S, P F\end{array}$ & $\begin{array}{l}14-25 \\
26-28\end{array}$ & $\begin{array}{l}419117 \\
442250\end{array}$ & $\begin{array}{r}188.7 \\
9.4\end{array}$ & $\begin{array}{r}219.7 \\
37.9\end{array}$ & $\begin{array}{r}837.8 \\
98.2\end{array}$ & $\begin{array}{l}2.7 \\
--\end{array}$ \\
\hline $\begin{array}{l}\text { U00002 } \\
\text { U00004 }\end{array}$ & $\begin{array}{ll}S, & F F \\
S, & P F\end{array}$ & $\begin{array}{l}26-29 \\
28-29\end{array}$ & $\begin{array}{l}442250 \\
442250\end{array}$ & $\begin{array}{l}18.9 \\
18.9\end{array}$ & $\begin{array}{l}75.8 \\
75.8\end{array}$ & $\begin{array}{l}196.3 \\
196.3\end{array}$ & $\begin{array}{l}-- \\
--\end{array}$ \\
\hline $\begin{array}{l}\text { D20030 } \\
\text { D20034 }\end{array}$ & $\begin{array}{ll}S, P F \\
S, F F\end{array}$ & $\begin{array}{l}30-35 \\
30-35\end{array}$ & $\begin{array}{l}442250 \\
442250\end{array}$ & $\begin{array}{l}-- \\
--\end{array}$ & $\begin{array}{l}-- \\
--\end{array}$ & $\begin{array}{l}-- \\
--\end{array}$ & - \\
\hline $\begin{array}{l}\text { a. C: } \\
\text { b. Cal } \\
\text { c. TRU } \\
\text { note b } \\
\text { d. Sti }\end{array}$ & $\begin{array}{l}\text { lulose } \\
\text { ed usir } \\
\text { ers gene } \\
\text { dation. } \\
\text { servic }\end{array}$ & $\begin{array}{l}\text { S: sar } \\
\text { overy Sup } \\
\text { using of } \\
\text { pers port } \\
\text { time of }\end{array}$ & $\begin{array}{l}\text { ter; PF: } \\
\text { Engineerir } \\
\text { e or Mobi } \\
00 \text { depos } \\
g ; \text { values }\end{array}$ & $\begin{array}{l}\text { ter; FF } \\
\text { ulatior } \\
\text { arch Lo } \\
\text { f tota } \\
\text { ailable }\end{array}$ & $\begin{array}{l}1 \text { filter. } \\
125 / 82 \text {, to } \\
\text { sis, not } \\
\text { ross filte }\end{array}$ & $\begin{array}{l}\text { mine } 137 \mathrm{C} \\
\text { d by dose } \\
\text { on each }\end{array}$ & $\begin{array}{l}\text { ding. } \\
\text { from } \\
1 .\end{array}$ \\
\hline
\end{tabular}




\section{REFERENCES}

1. K. K. S. Pillay, Radiation Effects on Ion Exchangers Used in Radioactive Waste Management, Pennsylvania State University, DOE Contract 520483-S.

2. H. Sanchez (EG\&G Idaho) conversation with T. Lookabill (General Public Utilities).

3. J. Massey 1 tr to Distribution, "Ion Exchange Material Selection Meeting Minutes of July 2, 1979," Chem Nuclear Systems, Inc., Technical Integration Office Doc. No. 007014015, July 24, 1979.

4. U.S. Department of Energy Submerged Demineralizer System Task Force, Evaluation of Increased Cesium Loading on Submerged Demineralizer System (SDS) Zeolite Beds, U.S. Department of Energy, DOE-NE-0012, May 1981 .

5. D. O. Campbell, E. D. Collins, L. J. King, J. B. Knauer, Evaluation of the Submerged Demineralizer System (SDS) Flowsheet for Decontamination of High-Activity-Level Water at the Three Mile Island Unit 2 Nuclear Power Station, Oak Ridge National Laboratory (Union Carbide), ORNL/TM-7448, JuTy 1980 .

6. D. 0. Campbell, E. D. Collins, L. J. King, J. B. Knauer, Process Improvement Studies for the Submerged Demineralizer System at the Three Mile Island Nuclear Power Station Unit 2, Oak Ridge National Laboratory (Union Carbide), ORNL/TM-7756, May 1982.

7. GPU Service Corporation, "Division III System Design Description for Submerged Demineralizer System for TMI Unit II Recovery," SAD 527-A Rev. 2, May 11, 1981.

8. Union Carbide Corp., Linde Division, "Linde Molecular Sieves Ion Exchange Bullet in IE-95 and A-50 Series." 

APPENDIX A

TMI-2 EPICOR II WASTE MANAGEMENT

$49-50$ 



\section{APPENDIX A \\ TMI-2 EPICOR I I WASTE MANAGEMENT}

The EPICOR II ion exchange system began operating late in 1979 to process the contaminated water in the Auxiliary and Fuel Handing Buildings. Figure A-1 shows the flowpath of water through the EPICOR II system. Of the 50 highly loaded first-stage liners (called prefilters) generated by the processing, two were selected for characterization to determine the condition of the ion exchange media, any residual liquid, the composition of contained gases, and the condition of the carbon steel liner. Figure A-2 shows a cutaway view of an EPICOR II prefilter liner. PF-16, the first liner selected for characterization, was shipped to Battelle Columbus Laboratories, and the examination completed. Characterization on the second liner, $\mathrm{PF}-3$, is due to be completed shortly. The following reports discuss EPICOR II processing and the efforts to date in characterizing and shipping the EPICOR liners:

McGoey, R. J., "Processing Three Mile Island Unit 2 Accident Radioactive Waste," 88th National Meeting of the American Institute of Chemical Engineers, June 9-12, 1980.

Battelle Columbus Laboratories, Preliminary Characterization of EPICOR II Prefilter 16 Liner, GEND INF-015, November 1981.

John M. Bower, Development of a Prototype Gas Sampler for EP ICOR II Prefilter Liners, GEND INF-025, September 1982.

J. L. Buelt, Feasibility of Vitrifying EPICOR II Organic Resins, GEND 012 , December 1982.

J. David Yesso, V. Pasupathi, and Larry Lowry, Final Characterization of PF-16 Liner, GEND 015, August 1982. 


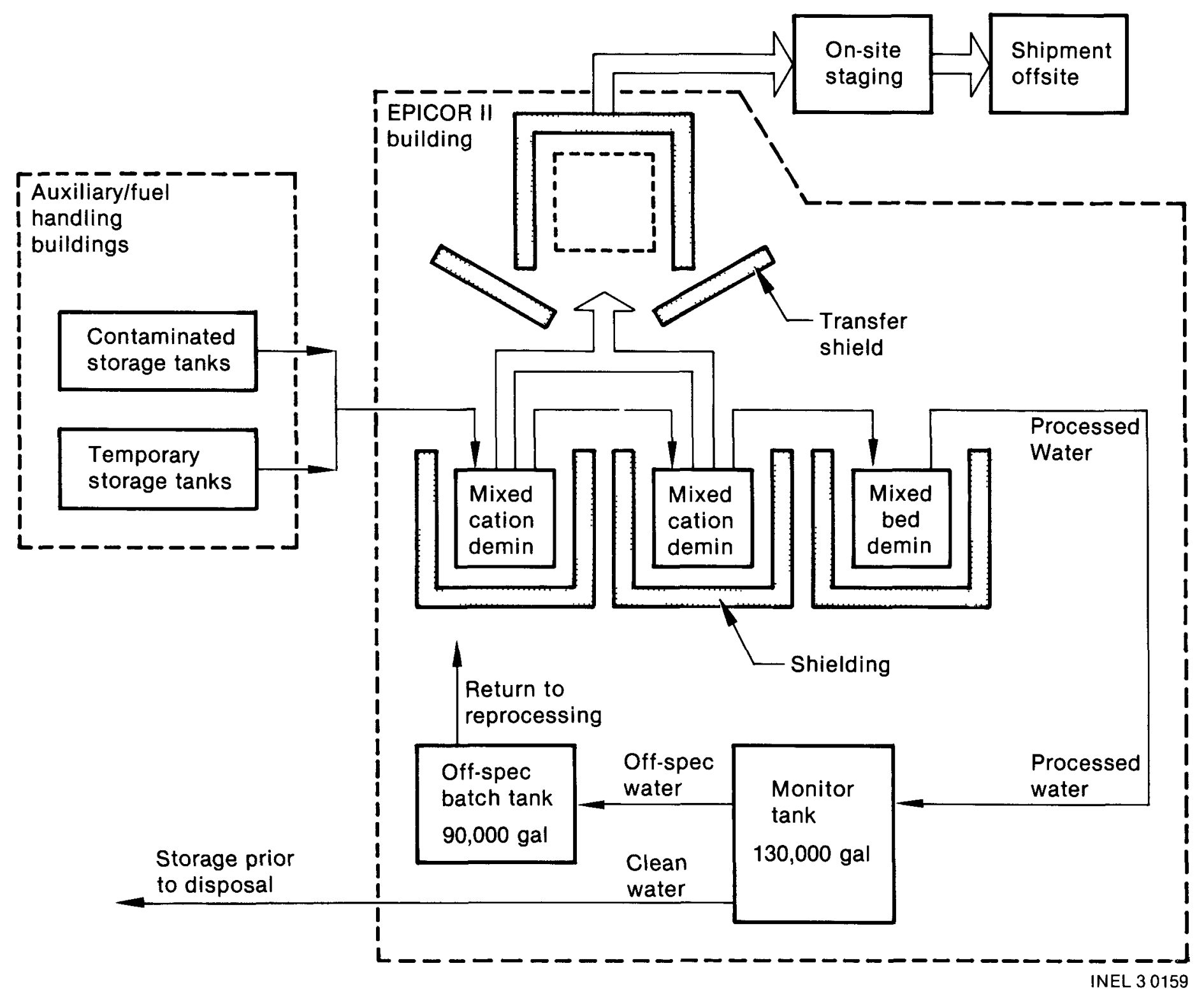

Figure A-1. Flowpath of water through the TMI-2 EPICOR II processing system. 


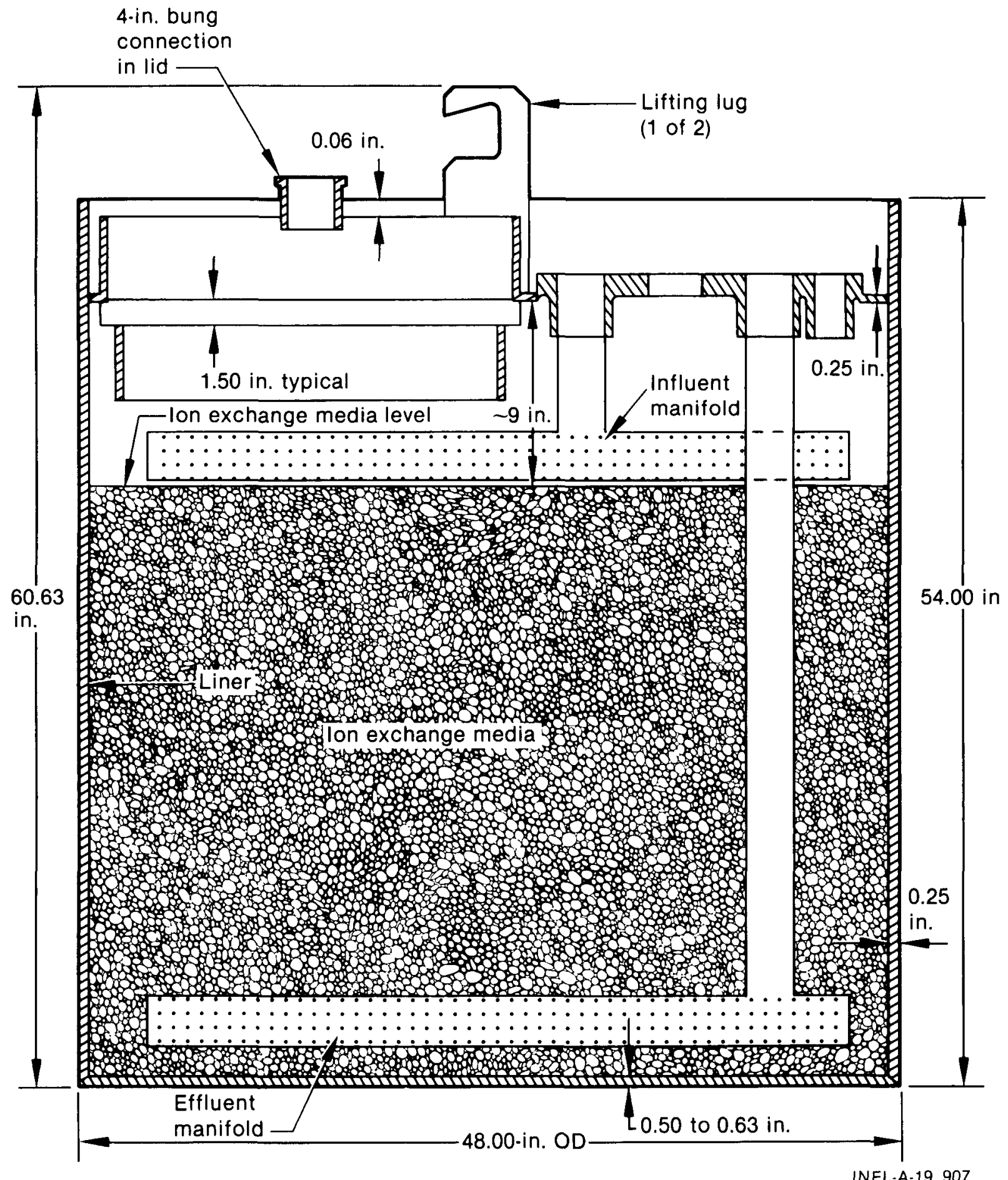

Figure A-2. Cross-sectional view of a typical EPICOR II liner. 
APPENDIX B

LOW SPECIFIC ACTIVITY WASTE

$55-56$ 
$-{ }_{-1}$ 


\section{APPENDIX B \\ LOW SPECIFIC ACTIVITY WASTE}

The low specific activity (LSA) waste generated at TMI-2 since the accident is routinely shipped to a commercial low-level waste burial site. Table B-1 lists approximate quantities of LSA wastes shipped from TMI-2 between 1979 and 1982. LSA waste is defined per 49 CFR 173.392 and includes compacted and uncompactable trash, and spent resin materials.

GPUNC has a drum compactor for volume reduction of TMI-2 LSA waste. Uncompactable waste is generally shipped in LSA boxes. Resins are shipped both unsolidified and solidified in cement depending upon curie loading.

TABLE B-1. APPROXIMATE QUANTITIES OF LOW SPECIFIC ACTIVITY WASTES SHIPPED TO COMMERCIAL BURIAL SITES

\begin{tabular}{ccc}
\hline Year & $\begin{array}{c}\text { Volume } \\
\left(\mathrm{ft}^{3}\right)\end{array}$ & \multicolumn{1}{c}{ Curie } \\
$1979^{\mathrm{a}}$ & 20,600 & 27 \\
1980 & 26,800 & 119 \\
1981 & 14,800 & 400 \\
1982 & $\underline{6,200}$ & -12 \\
\hline Total & 68,400 & 558 \\
\hline
\end{tabular}


APPENDIX C

10 CFR 20 CONCENTRATION LIMITS IN WATER ABOVE NATURAL BACKGROUND

$59-60$ 


APPENDIX C
10 CFR 20 CONCENTRATION LIMITS IN WATER

TABLE C-1. 10 CFR 20 CONCENTRATIONS IN WATER ABOVE NATURAL BACKGROUND

\begin{tabular}{|c|c|c|c|}
\hline \multirow[b]{2}{*}{$\begin{array}{c}\text { Element } \\
\text { (Atomic Number) } \\
\end{array}$} & \multirow[b]{2}{*}{ Isotope } & \multicolumn{2}{|c|}{$\begin{array}{c}\text { Concentrations in } \\
\text { Aqueous Effluents in } \\
\text { Unrestricted Areas } \\
\left(10^{-5}{ }_{\mu} \mathrm{Ci} / \mathrm{ml}\right)\end{array}$} \\
\hline & & Soluble & Insoluble \\
\hline Antimony (51) & $125 \mathrm{Sb}$ & 10.00 & 10.00 \\
\hline Cerium (58) & ${ }^{144} \mathrm{Ce}$ & 1.00 & 1.00 \\
\hline \multirow[t]{2}{*}{ Cesium (55) } & $134 \mathrm{Cs}$ & 0.90 & 4.00 \\
\hline & ${ }^{137} C_{s}$ & 2.00 & 4.00 \\
\hline Hydrogen (1) & $3 \mathrm{H}$ & 300.00 & 300.00 \\
\hline Ruthenium (44) & $106_{\mathrm{Ru}}$ & 1.00 & 1.00 \\
\hline \multirow[t]{2}{*}{ Strontium (38) } & ${ }^{89} s r$ & 0.30 & 3.00 \\
\hline & ${ }^{90} \mathrm{sr}$ & 0.03 & 4.00 \\
\hline
\end{tabular}


• 
APPENDIX D

SDS VESSEL NOMENCLATURE 
TABLE D-1. SDS VESSEL NOMENCLATURE

\begin{tabular}{|c|c|c|c|c|c|}
\hline Letter & $\begin{array}{l}\text { First } \\
\text { Digit }\end{array}$ & $\begin{array}{l}\text { Number } \\
\text { Made }\end{array}$ & $\begin{array}{l}\text { Number } \\
\text { Used }\end{array}$ & Manufacturing Company & Vessel Description and Use \\
\hline 0 & 0 & 11 & 4 & Applied Engineering Company (APCO) & $\begin{array}{l}\text { Sand pre- and final filter and leak- } \\
\text { age contaimment vessel }\end{array}$ \\
\hline $\mathrm{F}$ & 1 & 2 & 2 & APCO & Cellulose prefilter (1st position) \\
\hline $\mathrm{F}$ & 2 & 1 & 1 & APCO & $\begin{array}{l}\text { Cellulose final filter } \\
\text { (2nd position) }\end{array}$ \\
\hline D & 1 & 8 & 8 & Permutit & Ion exchange vesse 1 \\
\hline D & 2 & 16 & 7 & Buffalo Tank Division & Ion exchange vesse 1 \\
\hline D & 2 & 3 & 2 & Buffalo Tank Division & $\begin{array}{l}\text { Ion Exchange vessel: } \\
\text { vessels D-20030, } 34,36 \text { are } \\
\text { modified Buffalo, which were used as } \\
\text { pre- and final filter substitutes }\end{array}$ \\
\hline U & 0 & 5 & 3 & Buffalo Tank Division & $\begin{array}{l}\text { Universal sand pre and final filter } \\
\text { and leakage containment vessel: } \\
\text { influent manifold is modified } \\
\text { eliminating the internal strainer, } \\
\text { which restricts stream flow }\end{array}$ \\
\hline
\end{tabular}

